\title{
Article \\ Efficient In Vitro and In Vivo Anti-Inflammatory Activity of a Diamine-PEGylated Oleanolic Acid Derivative
}

\author{
Fatin Jannus ${ }^{1}{ }^{(D}$, Marta Medina-O'Donnell ${ }^{2, *}$, Veronika E. Neubrand ${ }^{3}{ }^{(D}$, Milagros Marín $^{1}$ (D), \\ Maria J. Saez-Lara ${ }^{1}$ (D) M. Rosario Sepulveda ${ }^{3}$ (D), Eva E. Rufino-Palomares ${ }^{1}$ (D), Antonio Martinez ${ }^{2}$,
} Jose A. Lupiañez ${ }^{1} \mathbb{D}$, Andres Parra ${ }^{2}$, Francisco Rivas ${ }^{2, * \mathbb{D}}$ and Fernando J. Reyes-Zurita ${ }^{1, *(\mathbb{D})}$

1 Department of Biochemistry and Molecular Biology I, Faculty of Sciences, University of Granada, Av. Fuentenueva, 18071 Granada, Spain; fatin@correo.ugr.es (F.J.); mmarin@ugr.es (M.M.); mjsaez@ugr.es (M.J.S.-L.); evaevae@ugr.es (E.E.R.-P.); jlcara@ugr.es (J.A.L.)

2 Department of Organic Chemistry, Faculty of Sciences, University of Granada, Av. Fuentenueva, 18071 Granada, Spain; aramon@ugr.es (A.M.); aparra@ugr.es (A.P.)

3 Department of Cell Biology, Faculty of Sciences, University of Granada, Av. Fuentenueva, 18071 Granada, Spain; neubrand@ugr.es (V.E.N.); mrsepulveda@ugr.es (M.R.S.)

* Correspondence: mmodonnell@ugr.es (M.M.-O.); frivas@ugr.es (F.R.); ferjes@ugr.es (F.J.R.-Z.); Tel.: +34-958-243-252 (F.J.R.-Z.)

Citation: Jannus, F.;

Medina-O'Donnell, M.; Neubrand, V.E..; Marín, M.; Saez-Lara, M.J..; Sepulveda, M..R.; Rufino-Palomares, E.E..; Martinez, A.; Lupiañez, J.A..; Parra, A.; et al. Efficient In Vitro and In Vivo Anti-Inflammatory Activity of a Diamine-PEGylated Oleanolic Acid Derivative. Int. J. Mol. Sci. 2021, 22, 8158. https://doi.org/10.3390/ ijms22158158

Academic Editor: Codruta Soica

Received: 15 June 2021

Accepted: 20 July 2021

Published: 29 July 2021

Publisher's Note: MDPI stays neutral with regard to jurisdictional claims in published maps and institutional affiliations.

Copyright: (c) 2021 by the authors. Licensee MDPI, Basel, Switzerland. This article is an open access article distributed under the terms and conditions of the Creative Commons Attribution (CC BY) license (https:/ / creativecommons.org/licenses/by/ $4.0 /)$.

\begin{abstract}
Recent evidence has shown that inflammation can contribute to all tumorigenic states. We have investigated the anti-inflammatory effects of a diamine-PEGylated derivative of oleanolic acid (OADP), in vitro and in vivo with inflammation models. In addition, we have determined the sub-cytotoxic concentrations for anti-inflammatory assays of OADP in RAW 264.7 cells. The inflammatory process began with incubation with lipopolysaccharide (LPS). Nitric oxide production levels were also determined, exceeding $75 \%$ inhibition of $\mathrm{NO}$ for a concentration of $1 \mu \mathrm{g} / \mathrm{mL}$ of OADP. Cell-cycle analysis showed a reversal of the arrest in the G0/G1 phase in LPS-stimulated RAW 264.7 cells. Furthermore, through Western blot analysis, we have determined the probable molecular mechanism activated by OADP; the inhibition of the expression of cytokines such as TNF- $\alpha$, IL-1 $\beta$, iNOS, and COX-2; and the blocking of p-IкB $\alpha$ production in LPS-stimulated RAW 264.7 cells. Finally, we have analyzed the anti-inflammatory action of OADP in a mouse acute ear edema, in male $\mathrm{BL} / 6 \mathrm{~J}$ mice treated with OADP and tetradecanoyl phorbol acetate (TPA). Treatment with OADP induced greater suppression of edema and decreased the ear thickness $14 \%$ more than diclofenac. The development of new derivatives such as OADP with powerful anti-inflammatory effects could represent an effective therapeutic strategy against inflammation and tumorigenic processes.
\end{abstract}

Keywords: oleanolic acid; triterpenes derivatives; diamine-(PEG)ylated oleanolic acid; OADP; anti-inflammatory mechanism; RAW 264.7 cell line; TPA-induced acute ear edema

\section{Introduction}

Inflammation is an innate natural process of the immune system. When persisting for a long period, this process can trigger various chronic diseases such as autoimmune disorders, arthritis, cardiovascular diseases, diabetes, Parkinson's, and cancer. In recent years, new natural compounds with anti-inflammatory properties have been identified and studied, offering the potential to decrease excessive inflammation associated with many diseases [1]. Our research group has recently investigated the anti-inflammatory effect of various diclofenac derivatives [2].

Previous studies have reported the in vitro and in vivo anti-inflammatory effects of various triterpenoids. Several triterpenic saponins have significantly reduced NO production in LPS-stimulated RAW 264.7 cells, inhibiting the release of pro-inflammatory cytokines, such as the tumor necrosis factor (TNF- $\alpha$ ), interleukine- $1 \beta$ (IL-1 $\beta$ ), interleukine6 (IL-6), and interleukine-8 (IL-8) [3]. In addition, SH479, a derivative of betulinic acid, 
ameliorated experimental autoimmune encephalomyelitis in a mouse model by modulating the Th17/Treg balance, on inhibiting the signal transducer and activator of transcription 3 (STAT3) and the nuclear factor kappa-light-chain-enhancer of activated B-cell (NF-kB) pathways and activating the STAT5 pathway [4]. Furthermore, oleanolic acid regulated the production of anti-inflammatory cytokines and decreased the production of pro-inflammatory cytokines in mice with experimental autoimmune myocarditis [5]. Similarly, in a mouse model of experimental autoimmune encephalomyelitis, oleanolic acid acetate suppressed the production of pro-inflammatory cytokines IL-1 $\beta$, IL-6, INF- $\gamma$, and TNF- $\alpha$ by regulating toll-like receptor 2 (TLR2) signaling [6]. A synthetic derivative of oleanolic acid (CDDO-Im) inhibited IL-6 and IL-17 expression and palliated dextran sulfate sodium (DSS) induced colitis in mice, as well as inhibited STAT3 activation [7]. Additional studies demonstrated that acetylated and methylated derivatives of oleanolic acid elicited a better anti-inflammatory response in male Wistar rat used as models of inflammation than did triterpenic acid $[8,9]$.

Olives are a rich source of pentacyclic triterpenes such as oleanolic and maslinic acids. Oleanolic acid is present in high concentrations in olive pomace, which represents $37 \%$ of the total triterpenoids in this fruit [10]. The concentration of this compound in extra virgin olive oil is $57.3 \mathrm{mg} / \mathrm{kg}$, whereas in pomace oil is $5592 \mathrm{mg} / \mathrm{kg}$. The greatest increase in triterpenes as the quality of the oil decreases is because these compounds are found mainly in the outer waxy layer of the olive fruit so that successive pressing and extractions favor their elimination [11]. In this study, oleanolic acid was obtained from solid olive oil wastes, using the method described in [12].

PEGylation is a technique that enables ethylene glycol units to bond to drugs, forming linear or branched polymers with different molar masses, which improve their biodistribution and bioavailability [13]. Our research group performed PEGylation reactions, covalently linking a polyethylene glycol (PEG) reagent to oleanolic acid (OA) and thereby producing a series of derivatives with greater solubility in aqueous media [14-16]. One of these PEGylated derivatives of oleanolic acid (OADP) has been studied due to its high cytotoxicity in Hep G2 cancer cells [17]. In the present study, we found that the cytotoxicity of OADP in human embryo WRL68 non-tumor liver cells was 39-fold lower than in the Hep G2 cancer cell line. Therefore, we studied the potential anti-inflammatory effect of OADP, since inflammation is related to cancer and plays a key role in tumorigenesis [18]. In this sense, an understanding of the molecular mechanisms involved in the inflammatory process can help to prevent certain chronic diseases and even some types of cancer.

In the inflammation process, different proteins such as protein kinases, PI3K/AKT, JAK, and MAPK are activated [19], so transcription factors such as STAT, AP-1 or NF- $\mathrm{kB}$ are activated, inducing the expression of pro-inflammatory proteins such as COX-2, iNOS, TNF- $\alpha$, IL-1 $\beta$, and IL- $6[20,21]$. Of these, COX-2 and iNOS produce the intermediates of the inflammation process, PGE-2 and nitric oxide (NO), respectively. In addition, $\mathrm{NO}$ can regulate the acute and chronic inflammatory process. COX-2 is activated in immune cells such as macrophages, producing PGs that induce different inflammatory states [22,23]. Disruption of the activation of this process can lead to aberrant cell growth, cancer cell transformation, angiogenesis, and metastasis. To evaluate the in vivo topical anti-inflammatory effects of OADP, we used the animal model of induced ear edema in mice [24]. In this model, inflammation is provoked by topical treatment with 12-Otetradecanoylphorbol 13-acetate (TPA), a phlogistic factor that causes the activation of MAP kinase proteins, activating the molecular pathway for the onset of the inflammatory process [25].

In this work, we examine the anti-inflammatory effect of OADP in LPS-stimulated RAW 264.7 cells and in mice having acute TPA-induced ear edema. Firstly, we conducted in vitro studies, determining $\mathrm{NO}$ release at different sub-cytotoxic concentrations of OADP after $72 \mathrm{~h}$ of incubation. The inhibition of NO production was accompanied by a reversal of G0/G1 phase arrest in LPS-stimulated RAW 264.7 cells. Secondly, we studied the underlying anti-inflammatory molecular mechanisms activated by OADP. Thus, OADP 
inhibited the expression of the main inflammatory cytokines such as TNF- $\alpha$, IL- $1 \beta$, iNOS, COX-2, and a regulated protein such as $\mathrm{p}-\mathrm{I} \kappa \mathrm{B} \alpha$. Furthermore, we evaluated the antiinflammatory effect in mice with acute ear edema by using a series of morphological measurements, histopathological analyses, and IL-6 induction levels.

\section{Results}

\subsection{Cytotoxicity of OADP in the Proliferation of RAW 264.7 Cells}

To evaluate the cytotoxic effects of OADP and OA on RAW 264.7 murine macrophage cells, we incubated these cells at increasing concentrations $(0-100 \mu \mathrm{g} / \mathrm{mL})$ of OADP for $72 \mathrm{~h}$ (Figure 1). Cell viability was analyzed using the MTT assay, where the tetrazolium dye was transformed into formazan in the mitochondria of viable cells, its absorbance measured at $570 \mathrm{~nm}$. The OADP concentration required for $50 \%$ cell growth inhibition $\left(\mathrm{IC}_{50}\right)$ after $72 \mathrm{~h}$ of incubation was less than $2 \mu \mathrm{g} / \mathrm{mL}\left(\mathrm{IC}_{50}=1.72 \pm 0.10 \mu \mathrm{g} / \mathrm{mL}\right)$, and was $56 \mu \mathrm{g} / \mathrm{mL}$ for OA. These cell viabilities with these compounds were determined to calculate the sub-cytotoxic concentrations at which to perform the anti-inflammatory tests. $\frac{3}{4} \mathrm{IC}_{50}=1.29 \mu \mathrm{g} / \mathrm{mL}, \frac{1}{2} \mathrm{IC}_{50}=0.86 \mu \mathrm{g} / \mathrm{mL}$, and $\frac{1}{4} \mathrm{IC}_{50}=0.43 \mu \mathrm{g} / \mathrm{mL}$ for OADP. $\frac{3}{4} \mathrm{IC}_{50}=41.78 \mu \mathrm{g} / \mathrm{mL}, \frac{1}{2} \mathrm{IC}_{50}=27.86 \mu \mathrm{g} / \mathrm{mL}$, and $\frac{1}{4} \mathrm{IC}_{50}=13.92 \mu \mathrm{g} / \mathrm{mL}$ for OA. These data for diclofenac were obtained from Galisteo et al. 2020 [2]. The use of these sub-cytotoxic concentrations ensures that the anti-inflammatory activity is due to an inflammatory process and not to its cytotoxicity.
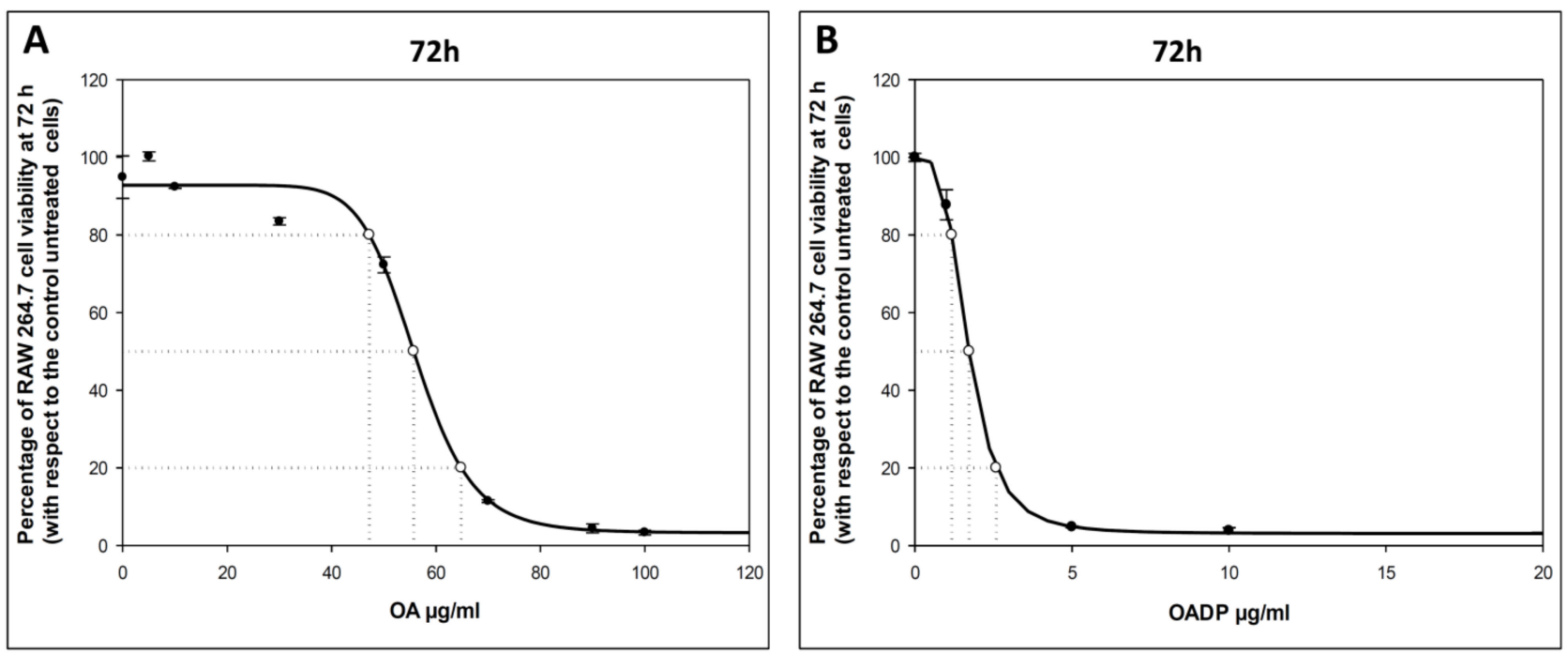

Figure 1. Effect of OA (A) and OADP (B) on cell proliferation of RAW 264.7 macrophage murine cells, after treatment with the compounds for $72 \mathrm{~h}$. Each point represents the mean value \pm S.D. of at least two independent experiments performed in triplicate.

\subsection{Nitric Oxide Production}

In the inflammation process, $\mathrm{NO}$ is produced by inducible nitric oxide synthase (iNOS) and, as the main pro-inflammatory mediator, plays a key role in the immune system. Murine macrophage cells RAW 264.7 were used to study the anti-inflammatory effect of OADP, which induces a significant release of NO during the inflammatory process. Therefore, the anti-inflammatory activity of OADP was assessed with the Griess method by measuring the nitrite concentration, proportional to the NO released, in the cell culture medium. These macrophages (RAW 264.7) were activated with LPS for $24 \mathrm{~h}$ after the addition of OADP. The following sub-cytotoxic concentrations were used: $\frac{3}{4} \mathrm{IC}_{50}, \frac{1}{2} \mathrm{IC}_{50}$, and $\frac{1}{4} \mathrm{IC}_{50}$.

NO production at 24,48 , and $72 \mathrm{~h}$ of incubation (Figure 2) was hardly detectable in the negative control (untreated cells), compared to the positive control (cells treated only 
with LPS). After $24 \mathrm{~h}$ of incubation, OADP did not cause any anti-inflammatory effect. Meanwhile, at $48 \mathrm{~h}$ of incubation, a slight anti-inflammatory effect was noted at the $\frac{3}{4} \mathrm{IC}_{50}$ concentration, with a $33 \%$ inhibition of $\mathrm{NO}$ production. However, $72 \mathrm{~h}$ of incubation gave rise to a strong anti-inflammatory effect at the $\frac{3}{4} \mathrm{IC}_{50}$ concentration, with $75 \%$ inhibition of NO production. In addition, slight anti-inflammatory effects were detected at the $\frac{1}{2}$ $\mathrm{IC}_{50}$ and $\frac{1}{4} \mathrm{IC}_{50}$ concentrations, with approximately $25 \%$ inhibition of NO production, with respect to the increase between the positive and negative control (Figure 2). At the concentrations tested, OA and diclofenac exerted no inhibitory effect on NO production in LPS-activated RAW 264.7 cells (Figure 3).

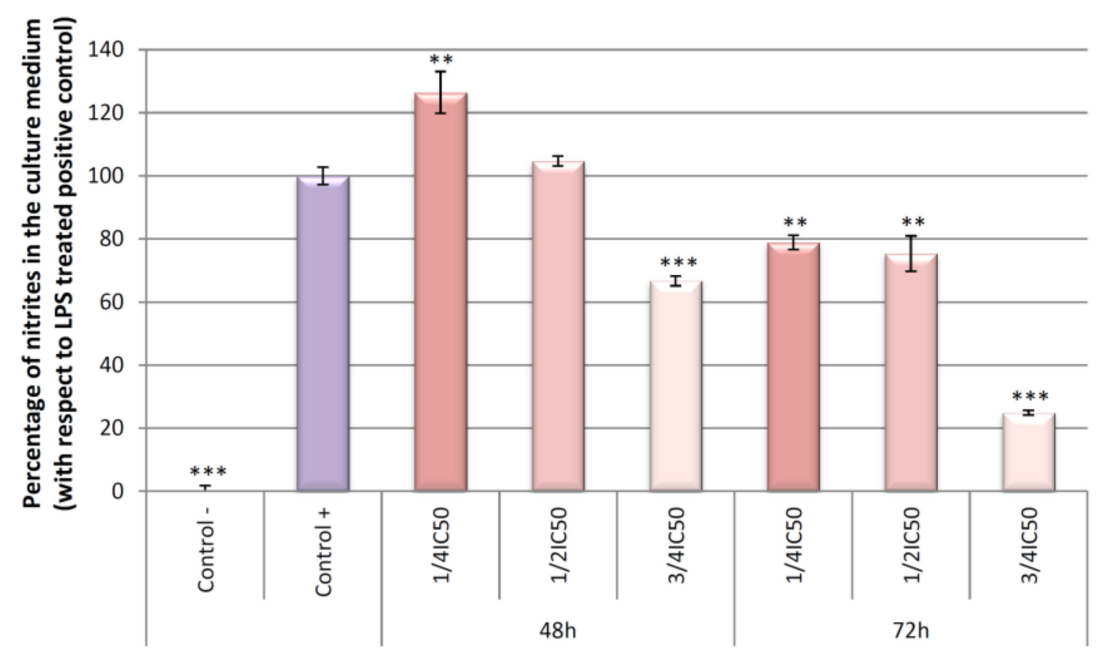

Figure 2. Effect of OADP on NO production in RAW 264.7 macrophage murine cells, after treatment with OADP for $48 \mathrm{~h}$ and $72 \mathrm{~h}$ at the $\frac{1}{2} \mathrm{IC}_{50}$ and $\frac{3}{4} \mathrm{IC}_{50}$ concentrations. Data represent the mean \pm S.D. of at least two independent experiments performed in triplicate. Key: $\left(^{* *}\right) p<0.01$ and $\left(^{* * *}\right) p<0.001$, with respect to LPS-treated control cells (positive control).

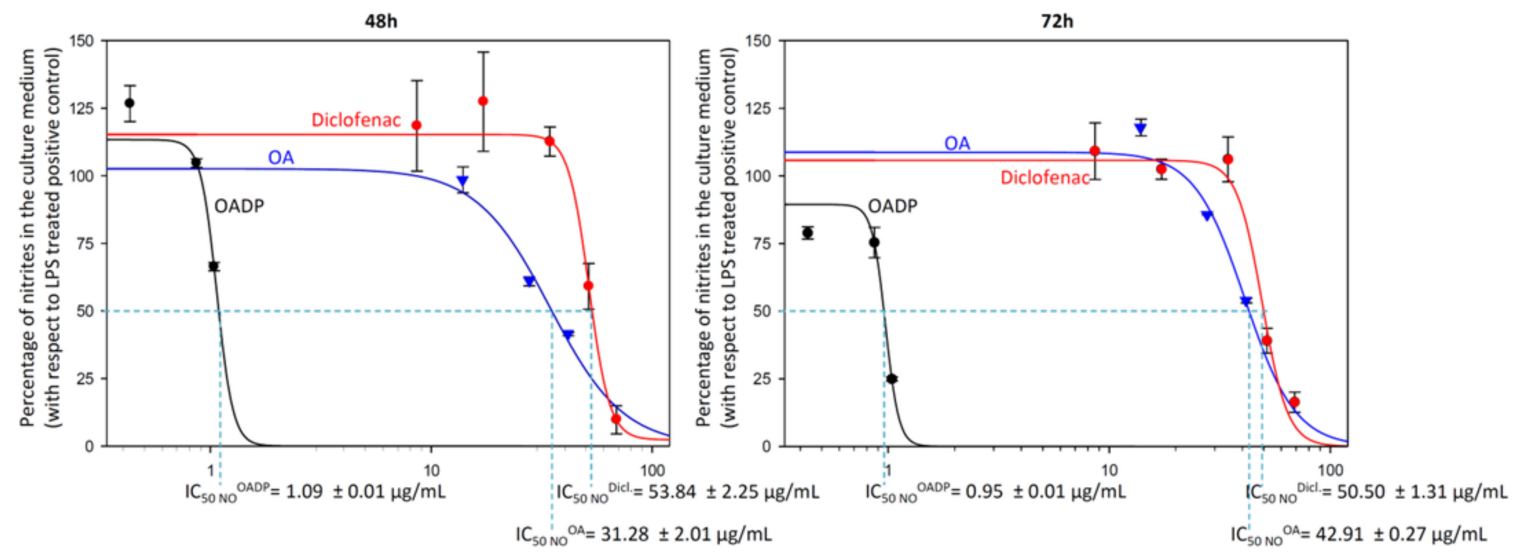

Figure 3. Sigmoidal curves of the effect of OADP (black), OA (blue) and diclofenac (red) on nitrite release in RAW 264.7 cells, after treatment with the compounds for $48 \mathrm{~h}$ and $72 \mathrm{~h}$. Data represent the mean \pm S.D. of at least two independent experiments performed in triplicate.

To compile more data on the anti-inflammatory effect of OADP, we calculated the doses that result in $50 \%$ NO inhibition ( $\mathrm{IC}_{50} \mathrm{NO}$ ) for OADP and compared them with those of $\mathrm{OA}$ and diclofenac, in each case at both $48 \mathrm{~h}$ and $72 \mathrm{~h}$ of treatment. The $\mathrm{IC}_{50 \mathrm{NO}}$ for OADP at $48 \mathrm{~h}(1.09 \pm 0.01 \mu \mathrm{g} / \mathrm{mL})$ and $72 \mathrm{~h}(0.95 \pm 0.01 \mu \mathrm{g} / \mathrm{mL})$ were significantly lower than for OA $(31.28 \pm 2.01 \mu \mathrm{g} / \mathrm{mL}$ for $48 \mathrm{~h}$ and $42.91 \pm 0.27 \mu \mathrm{g} / \mathrm{mL}$ for $72 \mathrm{~h})$ and diclofenac $(53.84 \pm 2.25 \mu \mathrm{g} / \mathrm{mL}$ for $48 \mathrm{~h}$ and $50.50 \pm 1.31 \mu \mathrm{g} / \mathrm{mL}$ for $72 \mathrm{~h}$ ) (Figure 3). Thus, OADP 
proved to be some 30-fold more anti-inflammatory than OA and about 50-fold more than diclofenac.

\subsection{Cell Cycle Arrest}

Flow cytometry with propidium iodide (PI) staining was used to evaluate the DNA ploidy and alterations in the cell-cycle profiles since the DNA content is directly proportional to the PI fluorescence, which indicates the percentage of cells in each phase of the cycle (Figure 4). RAW 264.7 cells were treated with LPS for $24 \mathrm{~h}$ to induce the inflammatory process, after which the cells were treated with OADP for $72 \mathrm{~h}$ at the corresponding subcytotoxic concentrations. A significant growth arrest occurred during the G0/G1 phase in the positive control (100\%) compared to the negative control (49.6\%). A DNA histogram analysis revealed that OADP was capable of reversing LPS-induced cell-cycle arrest in the G0/G1 phase. When the cells were treated with OADP at the corresponding sub-cytotoxic concentrations $\left(\frac{1}{4} \mathrm{IC}_{50}, \frac{1}{2} \mathrm{IC}_{50}\right.$, and $\left.\frac{3}{4} \mathrm{IC}_{50}\right)$, the percentage of cell-cycle arrest was significantly reduced in the G0/G1 phase by up to $40.4 \%, 43.6 \%$, and $45.9 \%$, respectively. This decrease in the percentage of cells in the G0/G1 phase was accompanied by a concomitant increase in the percentage of cells in the S phase $\left(58.5 \%\right.$ at $\frac{1}{4} \mathrm{IC}_{50}, 50.7 \%$ at $\frac{1}{2} \mathrm{IC}_{50}$, and $54.2 \%$ at $\left.\frac{3}{4} \mathrm{IC}_{50}\right)$. This recovery in the cell cycle could be a result of the anti-inflammatory effects caused by OADP, which appears to have stimulated cell division. These results show no significant variations for the different sub-cytotoxic concentrations used, indicating that OADP has anti-inflammatory effects at all the concentrations tested. The changes were not significant in the G2/M phase of the cell cycle.
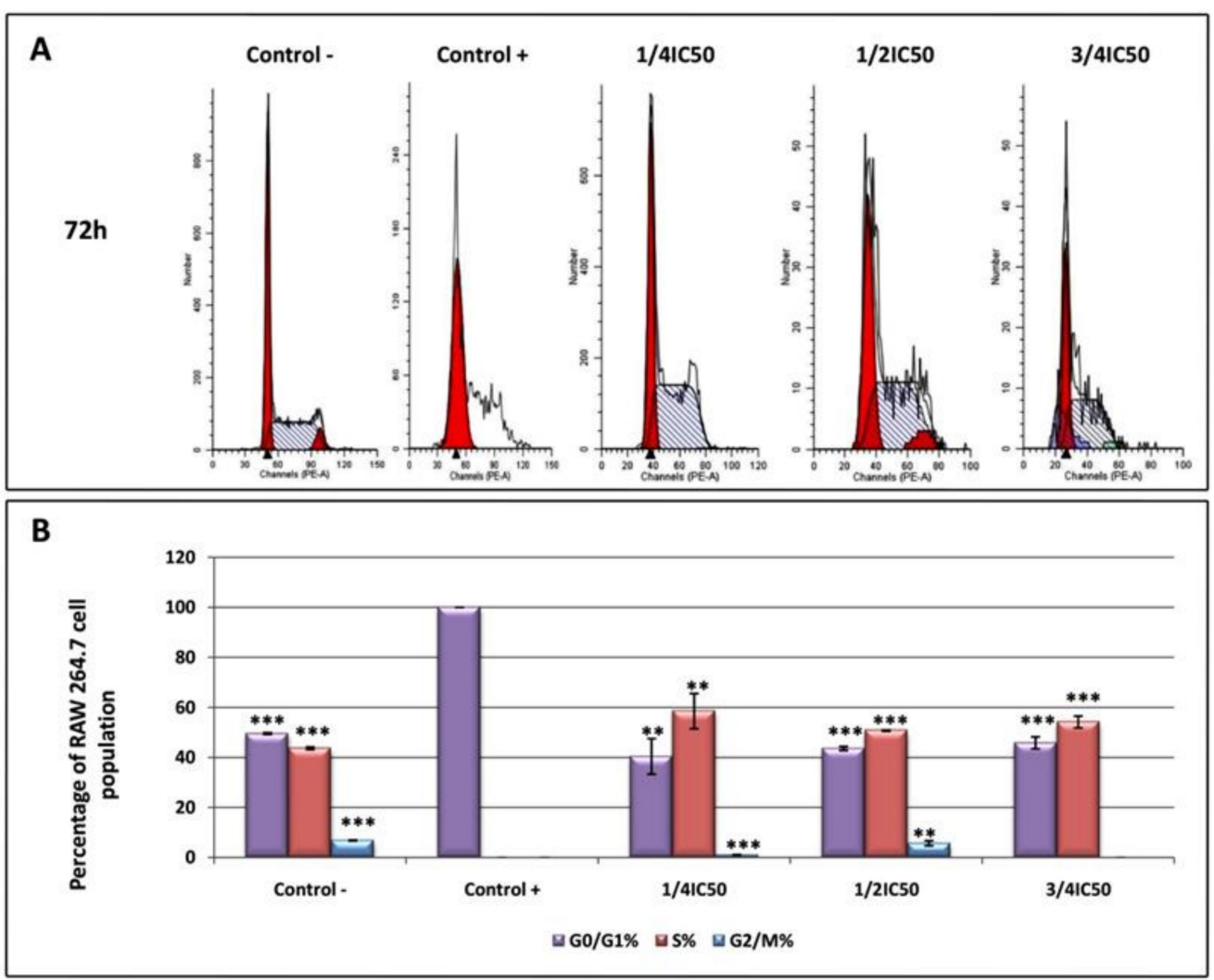

Figure 4. DNA histograms of cell cycle analysis of RAW 264.7 macrophage murine cell, after treatment with OADP for $72 \mathrm{~h}$ at the $\frac{1}{2} \mathrm{IC}_{50}$ and $\frac{3}{4} \mathrm{IC}_{50}$ concentrations (A). Percentage of RAW 264.7 macrophage murine cell population in the different phases of the cell cycle (G0/G1, S and G2/M) (B). Data represent the mean \pm S.D. of at least two independent experiments performed in triplicate. Key: $\left.{ }^{* *}\right) p<0.01$ and $\left.{ }^{* * *}\right) p<0.001$, with respect to LPS-treated control cells (positive control). 


\subsection{OADP-Induced Cell-Morphology Changes on LPS-Stimulated RAW 264.7 Cells}

The cell morphology of RAW 264.7 cells was analyzed in the presence as well as the absence of LPS and OADP. Treatment of LPS-stimulated RAW 264.7 cells with OADP for $72 \mathrm{~h}$ at the sub-cytotoxic $\frac{1}{4} \mathrm{IC}_{50}$ and $\frac{3}{4} \mathrm{IC}_{50}$ concentrations led to morphological changes. In general, untreated cells were smooth and round, whereas LPS-stimulated RAW 264.7 cells had changed to an irregular and rough shape with dendritic formations. Dendritic morphology was characterized by multiple prominent cytoplasmic projections. Co-treatment of LPS with OADP decreased the level of dendritic formation, showing a shape more similar to that of untreated cells, in a dose-dependent manner. The cells were visualized under optical microscopy (Figure 5).

\section{OADP 72h}

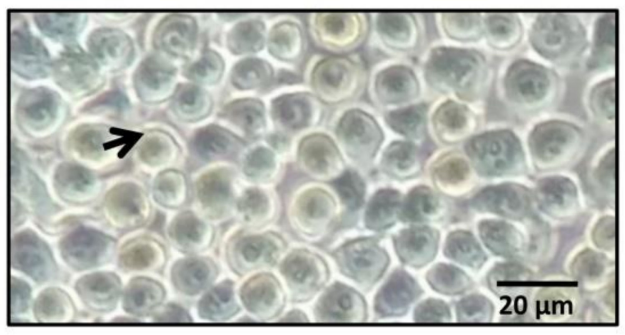

Control -

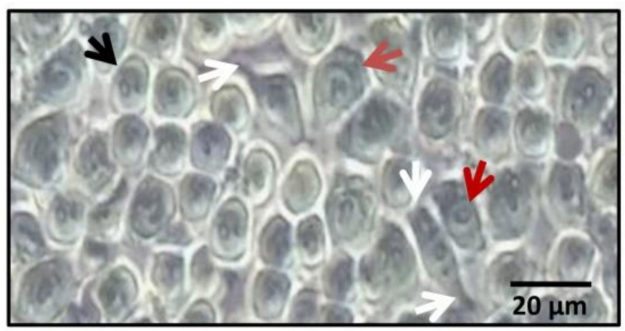

$1 / 2$ IC50

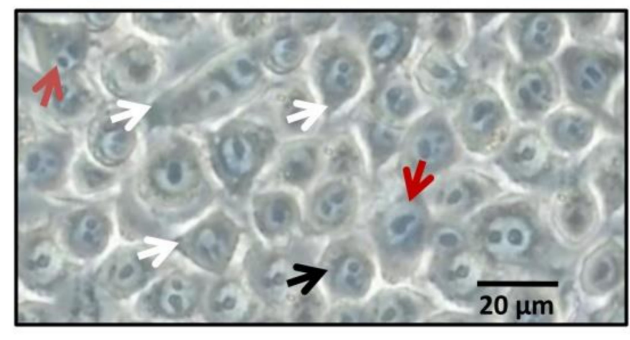

Control +

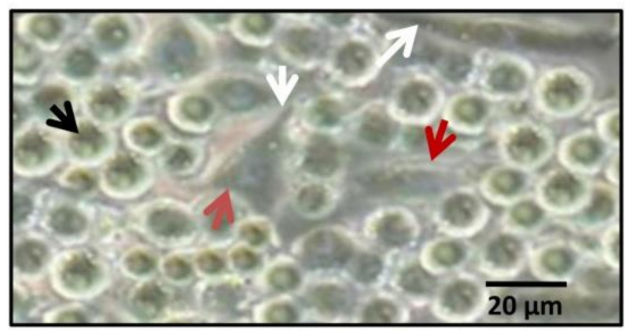

$3 / 4 I C 50$

Figure 5. Morphological transformation in RAW 264.7 cells stimulated with LPS and OADP treatment for $72 \mathrm{~h}$ at the $\frac{1}{2} \mathrm{IC}_{50}$ and $\frac{3}{4} \mathrm{IC}_{50}$ concentrations. The black arrows indicate Raw 264.7 cells in monocyte state. The red arrows indicate Raw 264.7 cells in macrophage state. The white arrows indicate cytoplasmic projections.

2.5. OADP-Induced Inhibition of the Expression of Pro-Inflammatory Proteins TNF- $\alpha$ and IL-1 $\beta$ on LPS-Stimulated RAW 264.7 Cells

The activation of pro-inflammatory cytokines is one of the central processes that occur during the induction of the inflammatory response. TNF- $\alpha$ and IL-1 $\beta$ are potent proinflammatory cytokines capable of recruiting immune cells and triggering inflammation. TNF- $\alpha$ is a pro-inflammatory cytokine produced by various immunocompetent cells, including macrophages, neutrophils, Th1/Th2 cells, and dendritic cells. IL-1 $\beta$ is a proinflammatory cytokine produced by B cells, endothelial cells, and fibroblast cells. However, its release is linked to an acute and chronic inflammatory process, inducing the acute-phase reaction and favoring prostaglandin synthesis. The results of the Griess test indicated that the strongest anti-inflammatory effect occurred after $72 \mathrm{~h}$ of incubation with OADP at the $\frac{3}{4} \mathrm{IC}_{50}$ concentration, accompanied by a weak anti-inflammatory effect at the $\frac{1}{2} \mathrm{IC}_{50}$ and $\frac{1}{4}$ $\mathrm{IC}_{50}$ concentrations. Therefore, using Western blot analysis, we examined the expression of the pro-inflammatory cytokines TNF- $\alpha$ and IL-1 $\beta$ after $72 \mathrm{~h}$ of incubation with OADP at $\frac{3}{4}$ $\mathrm{IC}_{50}$ and $\frac{1}{2} \mathrm{IC}_{50}$ concentrations. In this case, we found that the expression of TNF- $\alpha$ and IL-1 $\beta$ in RAW 264.7 cells increased significantly in the positive control (12-fold with respect to the TNF- $\alpha$ expression and 6-fold with respect to the IL-1 $\beta$ expression, compared to the negative control). Treatment with OADP prompted a concentration-dependent decline 
in the expression of these proteins. Thus, OADP significantly reduced the expression of TNF- $\alpha$ in RAW 264.7 cells $\left(32 \%\right.$ at $\frac{1}{2} \mathrm{IC}_{50}$ and $57 \%$ at $\frac{3}{4} \mathrm{IC}_{50}$ ) compared to the positive control (Figure 6A). Furthermore, the level of IL-1 $\beta$ lowered in RAW 264.7 cells ( $29 \%$ at $\frac{1}{2} \mathrm{IC}_{50}$ and $96 \%$ at $\frac{3}{4} \mathrm{IC}_{50}$ ) compared to the positive control (Figure $6 \mathrm{~B}$ ). Therefore, OADP proved capable of suppressing the synthesis and release of these cytokines, becoming a possible candidate for the development of new anti-inflammatory drugs.

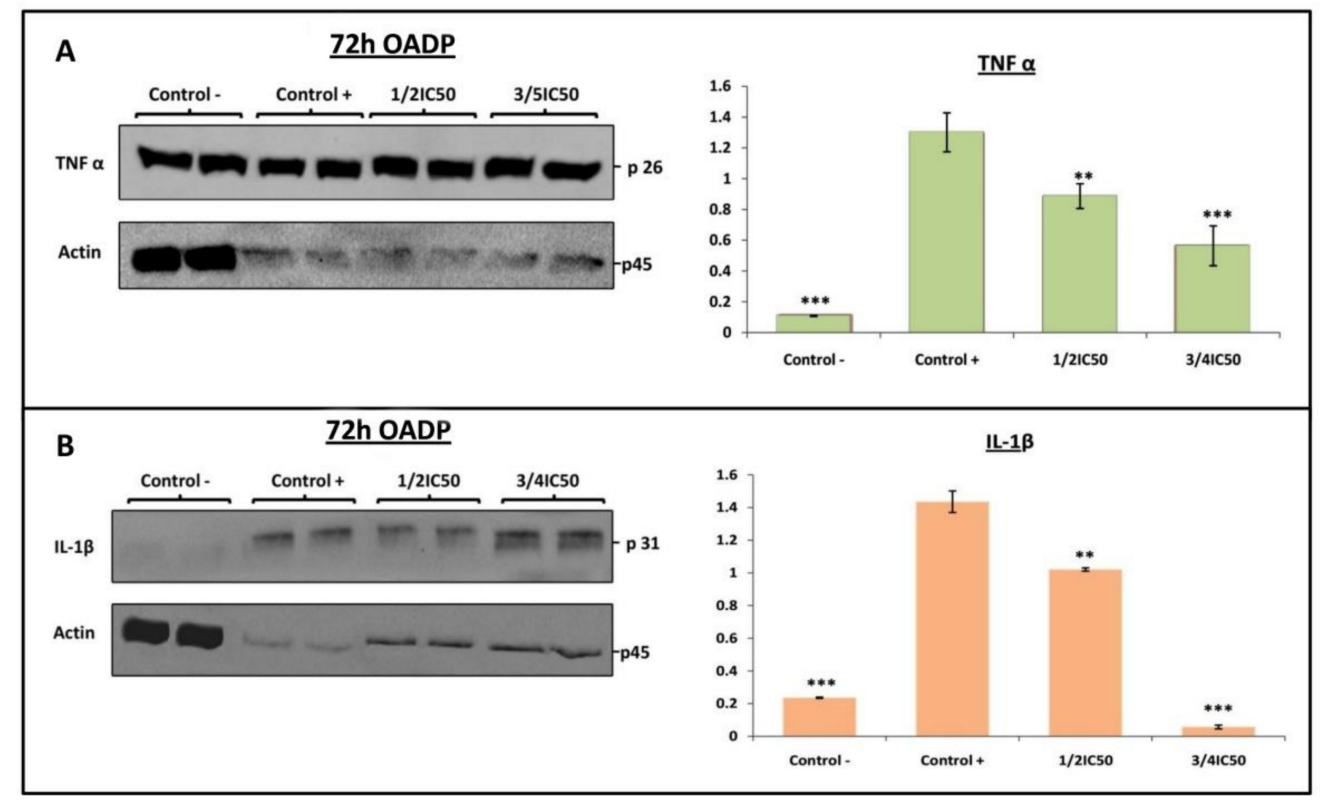

Figure 6. Western blot of the levels of TNF- $\alpha$ (A) (p26) and IL-1 $\beta$ (B) (p31) proteins on LPS-stimulated Raw 264.7 cells, after treatment with OADP for $72 \mathrm{~h}$ at the $\frac{1}{2} \mathrm{IC}_{50}$ and $\frac{3}{4} \mathrm{IC}_{50}$ concentrations. Protein expression levels are expressed as arbitrary intensity units for each band compared to arbitrary intensity units for actin (p45). Variations in the relative percentages of TNF- $\alpha$ and IL- $1 \beta$ expression for each concentration are also shown. The values represent means \pm S.D. of at least two separate experiments. Key: $\left(^{* *}\right) p<0.01$ and $\left(^{* * *}\right) p<0.001$, with respect to LPS-treated control cells (positive control).

\subsection{OADP-Induced Inhibition of COX-2, iNOS, and $p$-I $\kappa \mathrm{B} \alpha$ Protein Expression on LPS-Stimulated RAW 264.7 Cells}

The uncontrolled inflammatory process can lead to tissue damage and various inflammatory diseases, such as autoimmune disorders, cardiovascular diseases or tumorigenesis. It is well known that stress and inflammatory cytokines induce phosphorylation and stimulation of active NF- $\mathrm{KB}$, protein involved in the activation of the cell-proliferation process. Furthermore, NF- $\mathrm{kB}$ is the main transcription factor regulating the production of inflammatory proteins such as iNOS and COX-2, which are activated by cytokines TNF- $\alpha$ and IL-1 $\beta$ during immune responses.

In this context, the levels of two main inflammatory mediators such as COX-2 and iNOS were examined by Western blot analysis at $72 \mathrm{~h}$ after treatment with OADP $\left(\frac{3}{4} \mathrm{IC}_{50}\right.$ and $\frac{1}{2} \mathrm{IC}_{50}$ concentrations) in order to determine the anti-inflammatory effect caused in RAW 264.7 cells. The results indicate that in non-stimulated RAW 264.7 cells (negative control) iNOS and COX-2 expression was very low, whereas in LPS-stimulated cells (positive control) the protein levels rose markedly (14-fold with respect to iNOS expression and 10-fold with respect to COX-2 expression, compared to the negative control). As in the previous case, the treatment with OADP prompted a concentration-dependent decrease in the expression of these proteins. Therefore, OADP substantially reversed the high level of expression of COX-2 (56\% at $\frac{1}{2} \mathrm{IC}_{50}$ and $85 \%$ at $\left.\frac{3}{4} \mathrm{IC}_{50}\right)$ and $\mathrm{iNOS}\left(67 \%\right.$ at $\frac{1}{2} \mathrm{IC}_{50}$ and $81 \%$ at $\left.\frac{3}{4} \mathrm{IC}_{50}\right)$, induced by LPS treatment in a concentration-dependent manner, compared to the positive control (Figure 7A,B). 


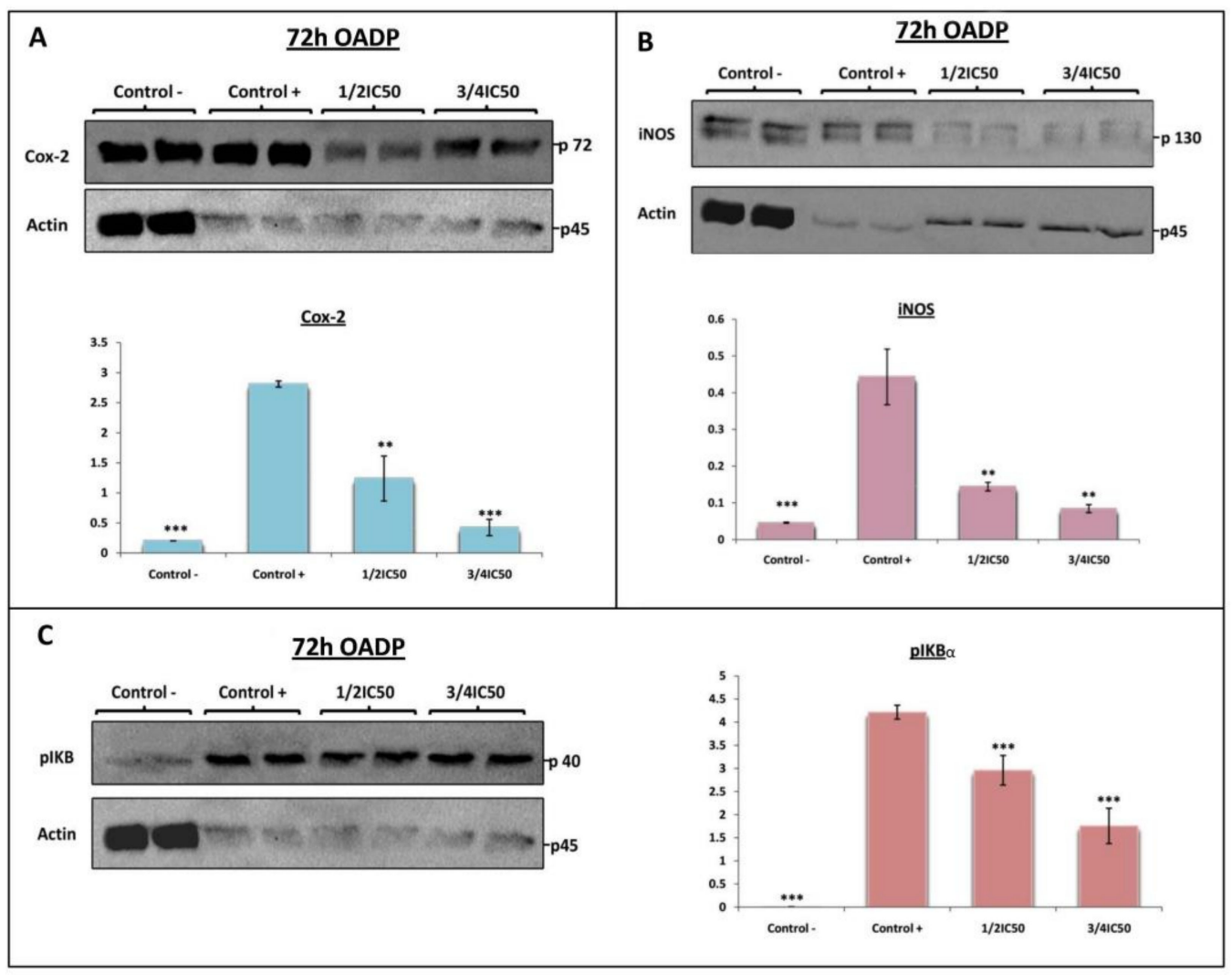

Figure 7. Western blot of the levels of proteins COX-2 (A) (p72), iNOS (B) (p130), and p-IкB $\alpha$ (p40) (C) on LPS-stimulated RAW 264.7 cells, after treatment with OADP for $72 \mathrm{~h}$ at the $\frac{1}{2} \mathrm{IC}_{50}$ and $\frac{3}{4} \mathrm{IC}_{50}$ concentrations. Protein expression levels are expressed as arbitrary intensity units for each band compared to arbitrary intensity units for actin (p45). Variations in the relative percentages of TNF- $\alpha$ and IL-1 $\beta$ expression for each concentration are also shown. The values represent means \pm S.D. of at least two separate experiments. Key: $\left({ }^{* *}\right) p<0.01$ and $\left(^{* * *}\right) p<0.001$, with respect to LPS-treated control cells (positive control).

The I $\kappa \mathrm{B} \alpha$ protein (NF- $\mathrm{B}$ inhibitory protein alpha) inhibited NF- $\mathrm{B}$, is inactivated and degraded by phosphorylation, resulting in $\mathrm{p}-\mathrm{I}_{\kappa} \mathrm{B} \alpha$. To further explore the anti-inflammatory role of OADP in LPS-stimulated Raw 264.7 cells, we used Western blot analysis to evaluate the expression level of the $\mathrm{p}-\mathrm{I} \kappa \mathrm{B} \alpha$ protein. This level rose some 480 -fold more in LPSstimulated Raw 264.7 cells than in the negative control (Figure 7C). In addition, OADP significantly reduced the expression level of the $\mathrm{p}-\mathrm{I} \kappa \mathrm{B} \alpha$ protein compared to the positive control. After treatment with LPS for $72 \mathrm{~h}$, the expression levels of the protein $\mathrm{p}-\mathrm{I} \kappa \mathrm{B} \alpha$ clearly increased, but a co-treatment with LPS and OADP at sub-cytotoxic concentrations significantly attenuated this expression in a dose-dependent manner $\left(30 \%\right.$ at $\frac{1}{2} \mathrm{IC}_{50}$ and $58 \%$ at $\frac{3}{4} \mathrm{IC}_{50}$ ), compared to the positive control (Figure $7 \mathrm{C}$ ). These results demonstrate that OADP clearly inhibited the expression of the $\mathrm{p}-\mathrm{I} \kappa \mathrm{B} \alpha$ protein in LPS-stimulated RAW 264.7 cells.

\subsection{OADP Inhibition of TPA-Induced Inflammation in Mouse Ear}

The results showed the clear induction of edema in response to treatment with TPA. Induction proved noticeable in all morphological measurements made, with an increase of approximately $25 \%$ to $40 \%$, when comparing the right ears with the left, in each of the parameters measured (Figure 8 ). Thus, the width increased by $25 \%(23.97 \pm 2.6 \%)$, the diameter of the external auditory canal by $30 \%(27.81 \pm 5.8 \%)$, and the weight of the 6-mm disc (removed from the ear as a sample) by $40 \%(37.42 \pm 5.6 \%)$. This effect was also appreciable in the phenotype presented by the right ear in the control mice (Figure 8D). 

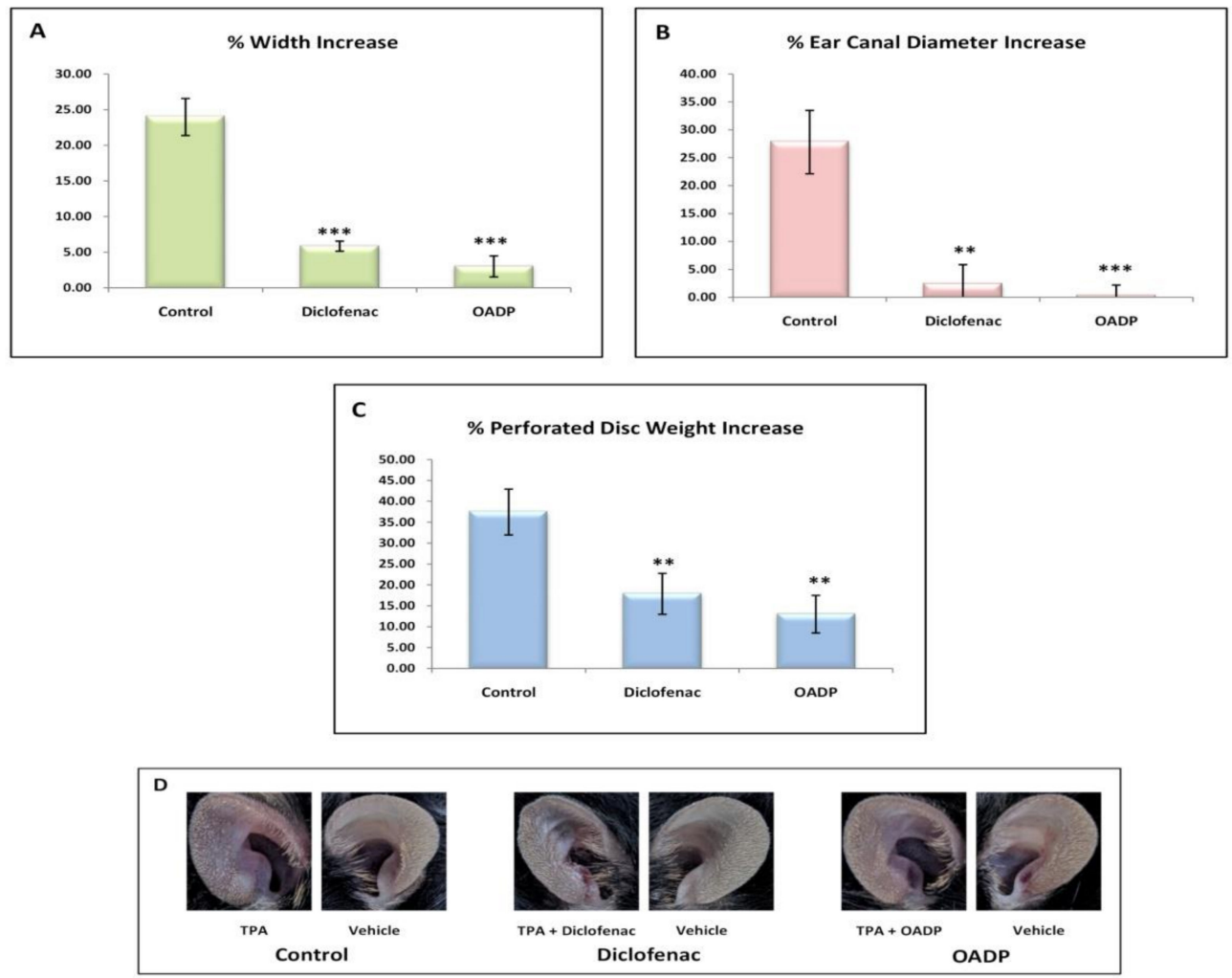

Figure 8. Increases in the percentage of the different morphological parameters: Width (A), diameter of the external auditory canal (B), and weight of the $6 \mathrm{~mm}$ disc practiced (C). These increases have been calculated from the differences between the left and right ears in the different groups of mice (Control, Diclofenac, OADP) (D). The mean \pm S.E.M. is shown for each of these parameters $(n=4)$.

The TPA-induced edema was significantly inhibited in OADP-treated mice, with virtually no changes between the right and left ear. The width increase $(2.99 \pm 1.48 \%)$ was $22 \%$ less than in the control. No differences were detected in the diameter change of the external auditory canal on comparing the two ears $(0.18 \pm 6.10 \%)$, this being some $30 \%$ less than in the control. The weight of the $6-\mathrm{mm}$ disc removed from the ear increase $(12.90 \pm 5.47 \%)$, being $24.5 \%$ less than in the control.

The results for the treatment with diclofenac were similar to those found with OADP, although higher values were registered for the increases in the different parameters evaluated: $5.83 \pm 0.71 \%$ in the width, $2.34 \pm 3.5 \%$ in the diameter of the external auditory canal, and $17.84 \pm 4.90 \%$ in the weight of the 6 -mm disc removed from the ear.

\subsection{OADP-Induced Decreases in TPA-Induced Mouse Ear Injury}

The main effect of OADP was studied in mouse edema biopsies in response to TPA treatment. In the control group, the right ear (treated with TPA) compared to the control left ear displayed intense tissue destruction and edema, with infiltrates of inflammatory polymorphonuclear leukocytes, mainly neutrophils, and hyperplasia as well as hypertrophy of the dermis and epidermis (vehicle, Figure 9A). However, pre-treatment with diclofenac and OADP significantly lowered the level of infiltration of edematous and inflammatory cells, compared to the control treated with TPA (Figure 9A). Furthermore, diclofenac and OADP reduced these impairments, markedly reducing ear thickness (by $21 \%$ and $35 \%$, respectively) compared to the TPA-treated control (Figure 9B). Topical pre-treatment with OADP alleviated the lesion more effectively than did diclofenac, as it notably depressed the development of erythema (Figure 9A,B). 


\section{A}

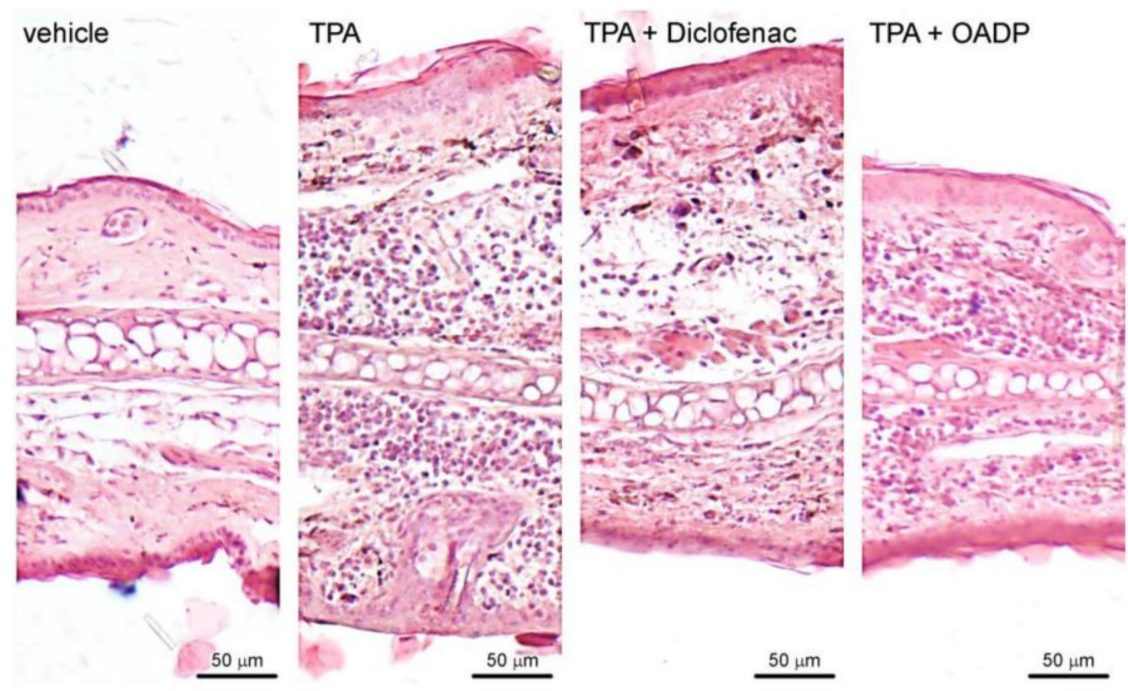

B

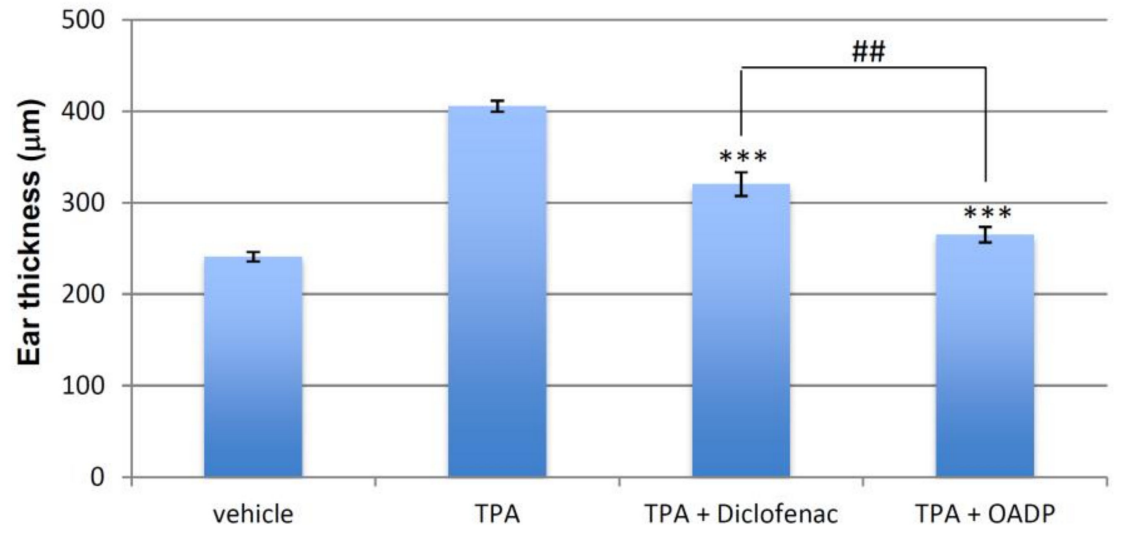

Figure 9. Representative photomicrographs. (A) The images show a cross section of the ears treated with vehicle (acetone), TPA alone, TPA + Diclofenac, TPA + OADP, at a 125x magnification. Scale bars $=50 \mu \mathrm{m}$. (B) The graph represents the mean thickness of the ear of each treatment, expressed as mean \pm S.E.M. $\left({ }^{* * *}\right) p<0.001$ compared to TPA treated ears. $\left({ }^{\# \#}\right) p<0.01$ compared to the ears treated with TPA + Diclofenac.

\subsection{OADP-Induced Decreases in IL-6 Released by TPA in the Mouse Ear}

Comparisons of the IL-6 concentrations between the right and left ear within each group of animals revealed a clear induction of inflammation in the control group, with an increase in IL-6 concentration of $91.84 \pm 20.23 \mathrm{pg} / \mathrm{mL}$ in the right ear compared to the left (Figure 10A). In the rest of the groups treated with the different inhibitors, including diclofenac, no increase was detected in the right ear compared to the left, and the interleukin- 6 concentration clearly decreased in this comparison (Figure 10B). Diclofenac lowered the IL-6 concentration by $180 \%(186.41 \pm 8.37 \%)$, while OADP caused a fall of almost $250 \%$, representing $60 \%$ stronger inhibition (Figure 10). Thus, regarding the production of IL-6, we conclude that OADP is clearly more efficient in vivo than is diclofenac. 

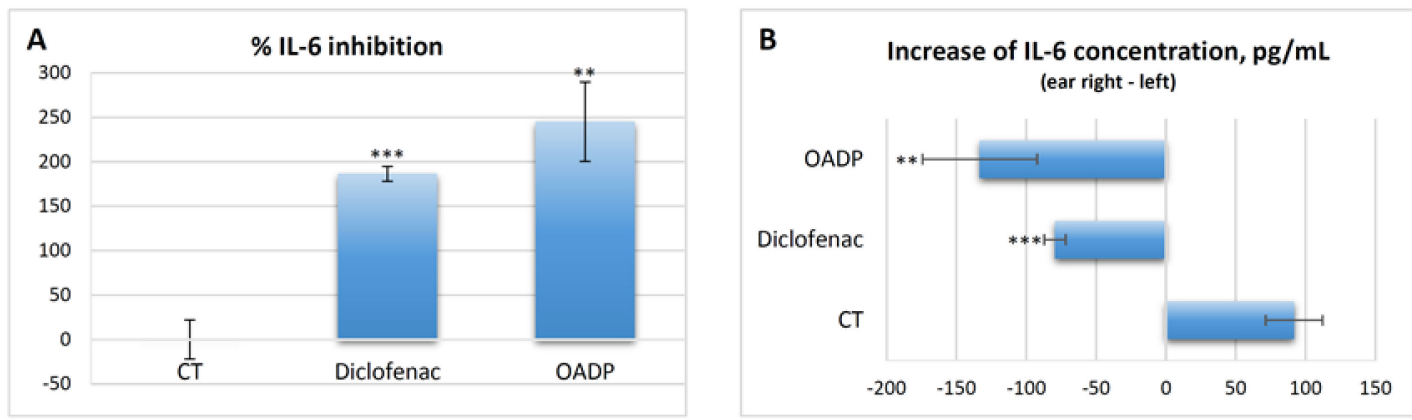

Figure 10. IL-6 inhibition percentage, calculated from the differences between the left and right ears in the different groups of mice (A). Increases in IL-6 concentration $(\mathrm{pg} / \mathrm{mL})$ calculated from the differences between the left and right ears in the different groups of mice (control, diclofenac and OADP) (B). The mean \pm S.E.M. is shown for each of these parameters $(n=4)$. Key: $\left.{ }^{* *}\right) p<0.01$ and $\left(^{* * *}\right) p<0.001$, with respect to the control group of mice.

\section{Discussion}

Inflammation is a common physiological response that when acute can be protective but when chronic can cause a wide variety of diseases, including cancer [26]. Therefore, inflammation becomes fundamental in tumor development, stirring intense interest in developing new anti-inflammatory agents that have significant anticancer properties [27]. Natural products, often used as an alternative to synthetic drugs in these types of afflictions, include oleanolic acid and its derivatives, which offer potential therapeutic effects in chronic diseases [28].

Previous results have shown that OADP can induce apoptosis at very low concentrations in different cancer cell lines $[16,17]$. In the present study, we examine the potential of OADP as an anti-inflammatory agent and investigate the underlying molecular mechanism for this effect in LPS-stimulated RAW 264.7 macrophage cells. Furthermore, we performed in vivo tests on a TPA-induced acute mouse ear edema model to evaluate the suppressive effect of OADP on pro-inflammatory mediators.

During the inflammation process, various types of leukocytes, lymphocytes, and other inflammatory cells are activated. Macrophages prove crucial in various inflammatory diseases by inducing the expression of pro-inflammatory mediators [29]. LPS is a strong inducer of monocytes to macrophages, stimulating the production of pro-inflammatory mediators [30]. Macrophage stimulation is represented by expanded cell size and extension of the cytoplasm. Other changes in stimulated macrophages serve to amplify the immune response [31]. OADP cytotoxicity was determined in murine monocyte/macrophage RAW 264.7 cells in order to establish sub-cytotoxic concentrations of this compound. The viability of these cells was tested at various OADP concentrations, using an MTT assay, which gave an $\mathrm{IC}_{50}$ concentration of $1.73 \mu \mathrm{g} / \mathrm{mL}$.

The primary pro-inflammatory mediator for acute or chronic inflammation is NO. In general, NO inhibitors provide excellent opportunities to design new therapeutic methods for inflammatory diseases [32]. In the present work, the inhibitory activity of OADP against NO release in LPS-stimulated RAW 264.7 cells is studied. OADP improved the NO inhibitory activity compared to the positive control (Figure 2). At $72 \mathrm{~h}$ of incubation, OADP resulted in $75 \%, 25 \%$, and $21 \%$ inhibition of NO, for concentrations of $\frac{3}{4} \mathrm{IC}_{50}, \frac{1}{2}$ $\mathrm{IC}_{50}$ and $\frac{1}{4} \mathrm{IC}_{50}$, respectively, with respect to the positive control. To compile more insight on this anti-inflammatory effect, we calculated the effective doses at $50 \%$ NO inhibition ( $\mathrm{IC}_{50 \mathrm{NO}}$ ) after $48 \mathrm{~h}$ and $72 \mathrm{~h}$ of treatment with OADP and found that the $\mathrm{IC}_{50 \mathrm{NO}}$ for OADP at $48 \mathrm{~h}$ were significantly lower than for OA and diclofenac, being 30 -fold more anti-inflammatory than OA and about 50-fold more than diclofenac (Figure 3). The flowcytometry results revealed the anti-inflammatory effect of OADP in RAW 264.7 cells at the corresponding sub-cytotoxic concentrations tested. Furthermore, OADP exhibited anti-inflammatory activity at $72 \mathrm{~h}$ of treatment by reversing the cell-cycle arrest induced by LPS (Figure 4). Morphological changes of RAW 264.7 cells were viewed under a light 
microscope $(\times 400)$. Untreated cells (negative control) were circular but became irregular in shape with multiple prominent cytoplasmic projections and dendritic formations, after stimulation with LPS (positive control). After $72 \mathrm{~h}$ of treatment with OADP, at different subcytotoxic concentrations, the degree of cell propagation and dendritic formation diminished markedly, in a dose-dependent manner (Figure 5).

The NF-KB and MAPK pathways are essential in regulating the production of inflammatory cytokines in activated macrophages such as TNF- $\alpha$, IL-1 $\beta$, and IL-6. TNF- $\alpha$ participates in various processes such as cell survival, apoptosis, and necrosis, by stimulating TNF receptors and related pathways, such as NF- $\mathrm{kB}$ and MAPKs [33]. The LPS-induced pattern of macrophage activation leads to high production of inflammatory mediators, such as TNF- $\alpha$, IL- $1 \beta$, and IL-6. This model is widely used to detect anti-inflammatory drugs [34].

Triterpenoids and their derivatives have an effective inflammatory effect both in vitro and in vivo. Inhibition of MAPKs pathways in the anti-inflammatory actions of several triterpenoids has been observed. For example, ursolic acid (UA) inhibited mitogen-induced phosphorylation of ERK and JNK and prevented the activation of immunomodulatory transcription factors such as NF- $\mathrm{kB}, \mathrm{NF}-\mathrm{AT}$, and AP-1 in T and B lymphocytes [35]. OA decreased the levels of TLR4 and NF-KB and MAPKs in the mouse model with salmonellainduced intestinal inflammation [36]. Indole OA derivatives, inhibited the expression of proteins of p-p38, p-JNK, p-ERK, p-NF- $k B$ p-Akt, iNOS and COX-2, and enhanced the expression of Nrf2 in LPS-activated BV2 cells [37].

Lupeol has been found to impede the expression of pro-inflammatory cytokines such as TNF $\alpha$ and IL- $\beta$ in LPS-stimulated macrophages [38]. Additional studies have shown that maslinic acid exerts an anti-inflammatory effect by inhibiting the production of NO induced by oxygen and glucose deprivation, TNF- $\alpha$ suppressing the expression of COX-2 and iNOS at the levels of protein and mRNA [39]. Maslinic acid reportedly exerts its anticancer effects on HT29 colon-cancer cells through a JNK-p53 dependent mechanism [40]. In a chemoprevention of tumorigenesis in ApcMin/+ mice, maslinic acid has been found to inhibit molecular pathways of inflammation and cell survival [41]. On the other hand, OA reportedly prevented colitis by inhibiting Th17 cells and the down-regulation of the expression of interleukin IL-1 $\beta$, NF-KB, MAPK, and ROR $\gamma \mathrm{t}$ in the colon [42]. CDDO-Me, a semi-synthetic derivative of $\mathrm{OA}$ has been found to induce downregulation of the expression of F4/80, CD11c, COX-2, IL-6, KI67, NF-B, and TNF- $\alpha$ [43].

In this context, to investigate whether the anti-inflammatory effects after $72 \mathrm{~h}$ of OADP treatment were associated with the activation of TNF $\alpha$ and IL-1 $\beta$, we performed a Western blot analysis and found that LPS markedly increased the production of TNF $-\alpha$ and IL- $1 \beta$ in inflammatory responses in RAW 264.7 cells. Meanwhile, OADP reversed the LPS-induced production of TNF- $\alpha$ and IL- $1 \beta$ after $72 \mathrm{~h}$ of treatment. In addition, a notable decrease in TNF- $\alpha$ expression was recorded in RAW 264.7 cells ( $32 \%$ at $\frac{1}{2} \mathrm{IC}_{50}$ and $57 \%$ at $\frac{3}{4} \mathrm{IC}_{50}$, Figure $6 \mathrm{~A})$, accompanied by a significant fall in the level of IL-1 $\beta$ ( $29 \%$ at $\frac{1}{2} \mathrm{IC}_{50}$ and $96 \%$ to $\frac{3}{4} \mathrm{IC}_{50}$, Figure $\left.6 \mathrm{~B}\right)$. These results imply that OADP has a protective effect on LPS-induced inflammation in RAW 264.7 cells. Thus, OADP is capable of suppressing the release of TNF- $\alpha$ and appears to be an excellent choice for use as a model in developing efficient anti-inflammatory drugs.

The two major enzymes iNOS and COX-2 induce the production of two crucial inflammatory mediators, NO and PGE2, respectively [44]. Furthermore, increased iNOS expression prompts high levels of $\mathrm{NO}$ and has been associated with various chronic inflammatory disorders [45]. Prostaglandin E2 (PGE2), biosynthesized by COX-2 from arachidonic acid, is a major inflammatory mediator, increasing local blood flow, pain sensitization, and edema. The inhibition or down-regulation of COX-2 expression blocks PGE2 synthesis and inhibits inflammation [46]. 
In the present work, the expression of COX-2 and iNOS was evaluated by Western blot analysis after $72 \mathrm{~h}$ of OADP treatment in LPS-activated RAW 264.7 cells. OADP exerted a gradual anti-inflammatory effect in a concentration-dependent manner from $\frac{1}{2} \mathrm{IC}_{50}$ to $\frac{3}{4}$ $\mathrm{IC}_{50}$, this effect being linked to the decline in the expression of COX-2 (56\% at $\frac{1}{2} \mathrm{IC}_{50}$ and $85 \%$ at $\left.\frac{3}{4} \mathrm{IC}_{50}\right)$ and $\mathrm{iNOS}\left(67 \%\right.$ at $\frac{1}{2} \mathrm{IC}_{50}$ and $81 \%$ at $\left.\frac{3}{4} \mathrm{IC}_{50}\right)$ (Figure $\left.7 \mathrm{~A}, \mathrm{~B}\right)$. Furthermore, the level of $\mathrm{p}-\mathrm{I} \kappa \mathrm{B} \alpha$ was studied at the corresponding sub-cytotoxic concentrations, revealing that phosphorylation of I $\mathrm{B} \alpha$ was significantly inhibited after treatment with OADP in a concentration-dependent manner (30\% at $\frac{1}{2} \mathrm{IC}_{50}$ and $58 \%$ at $\left.\frac{3}{4} \mathrm{IC}_{50}\right)$, relative to only the LPS-treated RAW 264.7 cells (positive control, Figure 7C).

The TPA-induced mouse ear edema model is widely used to study the anti-inflammatory activity of new compounds [47] Pentacyclic triterpene $\alpha$-amyrin inhibited TPA-induced activation of PKC $\alpha, E R K$, and p38 MAPK, thereby preventing I $\mathrm{B} B \alpha$ degradation and p65/RelA phosphorylation [48].

The anti-inflammatory effect of diclofenac and OADP was evaluated in mice having acute ear edema induced by TPA, and the treatment was found to be remarkably effective after $6 \mathrm{~h}$ of treatment. This anti-inflammatory effect was analyzed as a percentage of edema suppression in the treated groups, in contrast to the control group (vehicle), determining a series of morphological measurements. TPA caused a strong inflammatory process, characterized by a significant increase in the percentage of length, width, thickness, diameter of the external auditory canal and weight (Figure 8). However, treatment with diclofenac and OADP showed a significant anti-inflammatory effect by reducing these morphological measurements. These results were confirmed by a histopathological analysis (Figure 9), where OADP reduced edema and leukocyte infiltration better than did diclofenac. The production of IL-6 was also evaluated. Treatment with OADP stemmed IL-6 production more effectively than did the diclofenac treatment, resulting in a $250 \%$ inhibition in cytokine production, this being 60\% greater than with diclofenac (Figure 10).

In this sense, other triterpenoids such as Lupeol, have been effective against TPAinduced inflammation in acute ear edema mouse model, which also decreased myeloperoxidase levels causing a reduction in cellular infiltration in inflamed tissues, significantly inhibiting PGE2 levels [38]. Lupeol reduced cellularity and eosinophil levels in bronchoalveolar fluid [49]. This compound has also been shown effective against inflammation in the arthritis mouse model [50]. Another pentacyclic triterpenoid such as ursolic acid (UA) has shown anti-inflammatory activity in activated T cells, B cells and macrophages, and against graft-versus-host disease in vivo mouse model, significantly reducing serum levels of pro-inflammatory cytokines IL-6 and IFN- $\gamma$ [35]. Indole oleanolic acid derivatives inhibited the expression of pro-inflammatory cytokines (TNF- $\alpha$, IL-6, IL-12 and IL-1 $\beta$ ) and increased the expression of anti-inflammatory cytokine IL-10 [37].

With the results found and considering the bibliographic data on the anti-inflammatory action of triterpene compounds, the following molecular mechanism was proposed for the anti-inflammatory action of OADP (Figure 11). OADP could inhibit the activation of the TLR4 or TNFR2 receptors, preventing the activation of MAP kinases (ERK, JNK or p38) or inhibiting the phosphorylation of $\mathrm{I} \kappa \mathrm{B} \alpha$, which would lead to the inhibition of the activation of pro-inflammatory transcriptors such as NF-kB or the AP1 set (c-Jun, c-Fos, JunB, or JunD). Finally, all this could produce the inhibition of the expression of proinflammatory cytokines such as $\mathrm{TNF} \alpha, \mathrm{IL}-1 \beta$ or IL-6, and the proteins that are expressed in pro-inflammatory processes such as COX-2 or iNOS. 


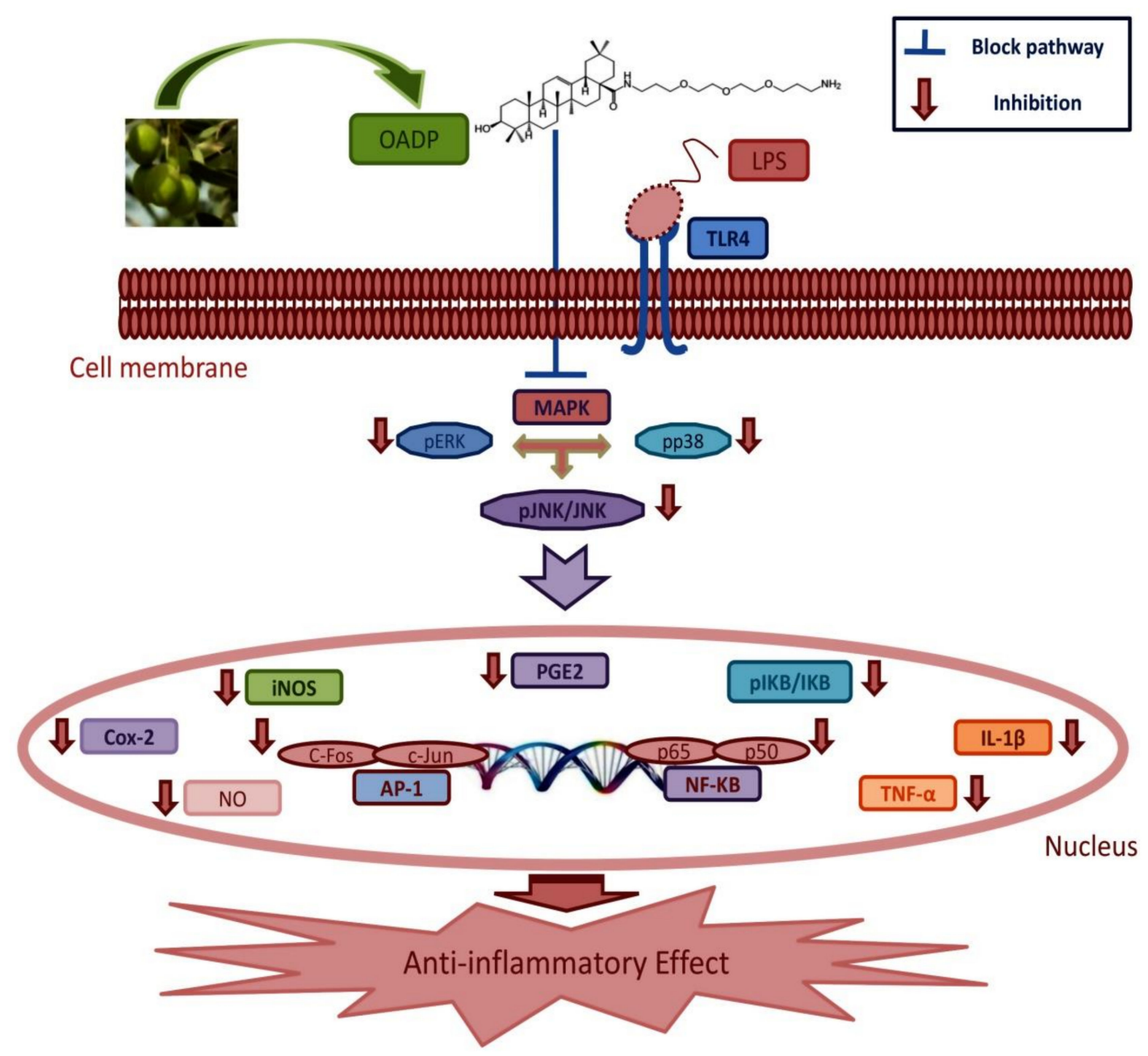

Figure 11. Mechanism of action underlying the anti-inflammatory effect induced by OADP in LPS-stimulated RAW264.7 cells, after $72 \mathrm{~h}$ of treatment, at the $\frac{1}{2}$ IC50 and $\frac{3}{4}$ IC50 concentrations. This process triggers the inhibition of phosphorylation of $\operatorname{I} \kappa \mathrm{B} \alpha$, the inhibition of the pro-inflammatory cytokines TNF- $\alpha$ and IL-1 $\beta$. Inhibition of the inflammatory mediators COX-2 and iNOS, induced inhibition of NO production.

The mouse model with acute ear edema has been chosen due to the low rate of suffering exerted in animals, compared to other tumorigenic inflammation models, in which TPA is used as a tumor promoter. For example, induction of skin carcinoma, in a two stages carcinogenesis mouse model [51], where the tumorigenic process is initiated with 7,12-dimethylbenz[a]-anthracene (DMBA) and the animals are treated for weeks with TPA. Our main objective in this article is to demonstrate the effectiveness of OADP as an anti-inflammatory agent and to study its behavior against inflammation induced by tumor promoters as TPA. OADP has been shown to be a very effective agent against tumor cell proliferation in HepG2 human hepatoma cancer cell line [17], and against inflammatory processes. Due to these results, we defend that OADP can be a good agent against tumorigenic processes. However, it will be necessary to accomplish future trials in inflammation models derived from cancer growth or genetic defects or chronic tissue degeneration/infection, similar to those performed with maslinic acid in intestinal tumorigenesis in ApcMin/+ mice [41]. Further studies will be necessary to establish the anti-inflammatory potential of OADP against chronic inflammation diseases such as arthritis or Parkinson's. In this sense, it would be interesting to determine the role of OADP to counteract inflammation after neurodegeneration, in microglia murine cell line model stimulated by LPS [52]. Although the anti-tumor and anti-inflammatory potential 
of OADP is clear, it will be necessary to perform all these studies before carrying out any clinical trials.

\section{Materials and Methods}

\subsection{Materials}

RPMI 1640 W/L-Glutamine, fetal bovine serum (FBS), gentamicin (Biowest, Nuaillé, France), DMSO (Merck Life Science S.L., Madrid, Spain), and 3-(4,5-dimethylthiazol-2-yl)2,5-diphenyltetrazolium bromide (MTT) (Thermo Fisher Scientific Inc., Ward Hill, MA, USA). IL-1 $\beta$, tumor necrosis factor alpha TNF- $\alpha$, p-IкB- $\alpha$, iNOS, and COX-2 primary antibodies, and anti-rabbit, anti-goat, and actin secondary antibodies were purchased from Santa Cruz Biotechnology (Santa Cruz, CA, USA). Phorbol ester 12-O-tetradecanoylphorbol13-acetate (TPA), culture flasks, and well plates were obtained from VWR International, Ltd. (Radnor, PA, USA).

\subsection{Test Compounds}

Oleanolic acid (OA) was isolated from solid olive oil production wastes, which were extracted successively in a Soxhlet extractor with hexane and EtOAc. Hexane extracts were a mixture from which $\mathrm{OA}$ was purified by column chromatography over silica gel followed by elution with $\mathrm{CH}_{2} \mathrm{Cl}_{2}$ /acetone mixtures of increasing polarity [12].

A solution of di-tert-butyl dicarbonate $\left(\mathrm{Boc}_{2} \mathrm{O}, 2.75 \mathrm{mmol}\right)$ in dried $\mathrm{CH}_{2} \mathrm{Cl}_{2}(2 \mathrm{~mL})$ was added slowly to a solution of 4,7,10-trioxatridecane-1,13-diamine $\left(\mathrm{H}_{2} \mathrm{~N}-\mathrm{PEG}-\mathrm{NH}_{2}\right.$, $6.8 \mathrm{mmol})$ in $\mathrm{CH}_{2} \mathrm{Cl}_{2}(20 \mathrm{~mL})$. The reaction mixture was maintained at room temperature for $12 \mathrm{~h}$, and then was diluted with water and extracted three times with $\mathrm{CH}_{2} \mathrm{Cl}_{2}$. After the organic layer was dried with anhydrous $\mathrm{Na}_{2} \mathrm{SO}_{4}$, the solvent was removed under reduced pressure, and thus the H2N-PEG-NH-Boc (85\%) was produced [16]. In a flask $(20 \mathrm{~mL})$, the compound H2N-PEG-NH-Boc $(0.45 \mathrm{mmol})$ was dissolved in DMF $(5 \mathrm{~mL})$ and afterwards OA ( $2 \mathrm{mmol})$, HOAt ( $3 \mathrm{mmol})$, PyAOP (2 mmol), and DIPEA ( $8 \mathrm{mmol})$, were added. The reaction mixture was heated at $100{ }^{\circ} \mathrm{C}$ for $12 \mathrm{~h}$, diluted with water and extracted three times with $\mathrm{CH}_{2} \mathrm{Cl}_{2}$. The organic layer was dried with anhydrous $\mathrm{Na}_{2} \mathrm{SO}_{4}$ and the solvent was removed under reduced pressure. Finally, the residue was purified by column chromatography, yielding the OA-diamine-Boc-PEGylated derivative (94\%) [16]. After this OA-diamine-Boc-PEGylated derivative $(0.3 \mathrm{mmol})$ was dissolved in THF $(20 \mathrm{~mL})$, concentrated $\mathrm{HCl}(37 \%, 2 \mathrm{~mL})$ was added. The reaction mixture was maintained at room temperature for $24 \mathrm{~h}$, and then was diluted with water and extracted three times with $\mathrm{CH}_{2} \mathrm{Cl}_{2}$. The organic layer was dried with anhydrous $\mathrm{Na}_{2} \mathrm{SO}_{4}$, and the solvent was removed under reduced pressure. Finally, the residue was purified by column chromatography, yielding OADP (95\%) [16].

Finally, OA and OADP (Figure 12) were dissolved in DMSO at $5 \mathrm{mg} / \mathrm{mL}$ and stored at $-20{ }^{\circ} \mathrm{C}$. Prior to treatment, the stock solution was diluted in cell culture medium to the appropriate concentration for each experiment.

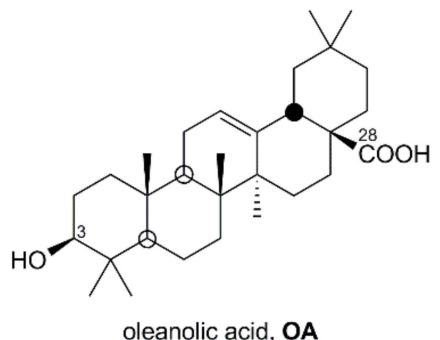

oleanolic acid, OA

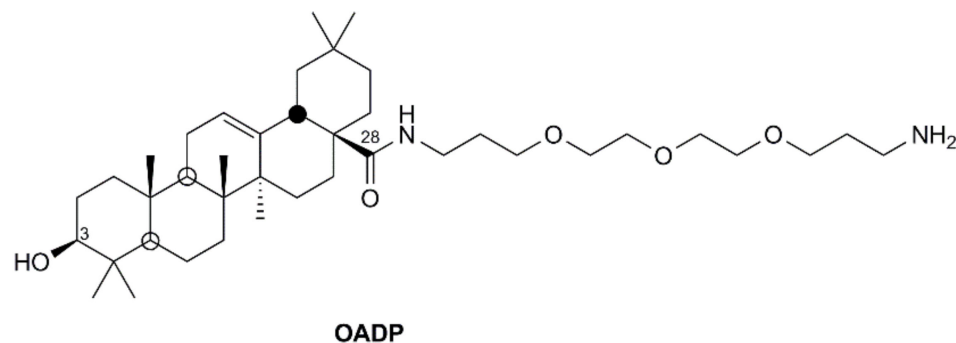

OADP

Figure 12. Structures of triterpene compounds OA and OADP. 


\subsection{Cell Culture}

The RAW 264.7 monocyte/macrophage cell line (ATCC no. TIB-71) is a murine leukemia virus-induced tumor cell line from mouse Mus musculus. This cell line does not produce detectable retrovirus. The RAW 264.7 cell line was cultured in RPMI1640 medium, supplemented with $2 \mathrm{mM}$ glutamine, $10 \%$ heat-inactivated FCS, $0.5 \mu \mathrm{g} / \mathrm{mL}$ of gentamicin, and incubated at $37{ }^{\circ} \mathrm{C}$ in a $5 \%$ atmosphere of $\mathrm{CO}_{2}$ at $95 \%$ humidity. Cells were grown to $80-90 \%$ confluence in sterile cell-culture flasks. Sub-confluent monolayer cells were used in all experiments. The cell line was provided by the cell bank of the University of Granada, Spain.

\subsection{Cell-Viability Assay}

The OA and OADP assay on RAW 264.7 cells was evaluated using the MTT proliferation assay. Cell viability was evaluated by measuring the absorbance of MTT staining of live cells. For this test, $6 \times 10^{3}$ RAW 264.7 cells were grown in a 96-well plate and subsequently incubated with OA and OADP at different concentrations $(0-100 \mu \mathrm{g} / \mathrm{mL})$. After $72 \mathrm{~h}$ of incubation, $100 \mu \mathrm{L}$ of MTT solution $(0.5 \mathrm{mg} / \mathrm{mL})$ in $50 \%$ of PBS with $50 \%$ of medium was placed in each well. After $1.5 \mathrm{~h}$ of incubation, the formazan was resuspended in $100 \mu \mathrm{L}$ of DMSO. Finally, the relative cell viability, with respect to the untreated control cells, was evaluated by absorbance at $570 \mathrm{~nm}$ in an ELISA plate reader (TecanSunrise MR20-301, TECAN, Austria). The experimental data were fitted to a sigmoid function $\left(y=y \max /(x / a)^{-b}\right)$ by non-linear regression. $\mathrm{IC}_{50}$ values were obtained by interpolation. Similar analyses were performed to determine the $\mathrm{IC}_{50} \mathrm{NO}$ of $\mathrm{NO}$ production (vide infra). All these analyses were performed with the statistical software SigmaPlot (Version 12.5). The values of cell viability were expressed as means \pm S.D. of at least two experiments performed in quadruplicate for each concentration.

\subsection{Determination of the NO Concentration}

The nitrite concentration was used as an indicator of NO production. The determination of the nitrite concentration in the culture medium was evaluated according to the Griess reaction. Cells were plated at $6 \times 10^{4}$ cells/well in 24-well cell culture plates and supplemented with $10 \mu \mathrm{g} / \mathrm{mL}$ of LPS. After $24 \mathrm{~h}$ of plating, cells were incubated for 24,48 , and $72 \mathrm{~h}$ with $\mathrm{OADP}$ at $\frac{1}{4} \mathrm{IC}_{50}, \frac{1}{2} \mathrm{IC}_{50}$, and $\frac{3}{4} \mathrm{IC}_{50}$ concentrations. The supernatants were collected at $24 \mathrm{~h}, 48 \mathrm{~h}$, and $72 \mathrm{~h}$ to determine their nitrite concentration and/or stored at $-80{ }^{\circ} \mathrm{C}$ for later use. The Griess reaction was performed by taking $150 \mu \mathrm{L}$ of supernatant test sample or the sodium nitrite standard $(0-120 \mu \mathrm{M})$, mixing with $25 \mu \mathrm{L}$ of Griess reagent A [0.1\% N-(1-naphthyl)ethylenediamine dihydrochloride] and $25 \mu \mathrm{L}$ of Griess reagent B ( $1 \%$ sulphanilamide in $5 \%$ of phosphoric acid) in a 96-well plate. After 15 min of incubation at room temperature, the absorbance at $540 \mathrm{~nm}$ was determined in an ELISA plate reader (Tecan Sunrise MR20-301, TECAN, Austria). The absorbance was referred to the nitrite standard curve to determine the nitrite concentration in the supernatant of each experimental sample. The percentage of NO production was determined, assigning $100 \%$ to the increase between the negative control (untreated cells) and the positive control (cells treated only with $10 \mu \mathrm{g} / \mathrm{mL}$ of LPS). The values of NO concentration were expressed as means \pm S.D. of at least two experiments performed in triplicate for each concentration.

\subsection{Cell-Cycle Analysis}

PI staining flow cytometry constitutes a fast, efficient, and reproducible method for determining relative DNA content. Flow cytometry provides an estimate of alterations in cell-cycle profiles and characteristic changes in DNA levels of cell-cycle arrest and cell differentiation. The number of cells at each stage of the cell cycle is determined by fluorescence-associated cell sorting (FACS) at $488 \mathrm{~nm}$ on an Epics XL flow cytometer (Coulter Corporation, Hialeah, FL, USA). For this test, $12 \times 10^{4}$ LPS-stimulated murine macrophage/monocyte RAW 264.7 cells were placed in 24-well plates with $1.5 \mathrm{~mL}$ of medium and incubated with OADP for $24 \mathrm{~h}$ at $\frac{1}{4} \mathrm{IC}_{50}, \frac{1}{2} \mathrm{IC}_{50}$, and $\frac{3}{4} \mathrm{IC}_{50}$ concentrations. 
The positive control consisted of cells treated only by LPS stimulation, while the negative control comprised cells not treated with LPS. The treated cells were LPS-stimulated RAW 264.7 cells and cells treated with the compounds under study. Subsequently, the cells were washed twice with PBS, harvested by tripsinization, and then resuspended in TBS 1X (10 Mm Tris, $150 \mathrm{Mm} \mathrm{NaCl}$ ), after which Vindelov Buffer (100 mM Tris, $100 \mathrm{Mm} \mathrm{NaCl}$, $10 \mathrm{mg} / \mathrm{mL}$ RNAse, and $1 \mathrm{mg} / \mathrm{mL} \mathrm{PI})$ at $\mathrm{pH} 8.0$ was added. The samples were placed on ice for $15 \mathrm{~min}$. Immediately before FACS analysis, the cells were stained with $20 \mu \mathrm{L}$ of $1 \mathrm{mg} / \mathrm{mL}$ PI solution. The data were analyzed with the Multicycle software to determine the percentage of cells in each phase of the cell cycle (G0/G1, S, and G2/M). The values of cell percentage were expressed as means \pm S.D. of at least two experiments performed in triplicate for each concentration.

\subsection{Western Blot Analysis}

RAW 264.7 cells $\left(12 \times 10^{4}\right)$ were treated with OADP at the sub-cytotoxic concentrations cited above, for $72 \mathrm{~h}$. The positive control consisted of cells treated only with LPS stimulation while the negative control was made up of untreated cells without LPS. After the treatments, cells were washed twice with PBS and resuspended in lysis buffer (20 mM Tris/acetate, pH 7.5, 1 mM EDTA, 1 mM EGTA, 1\% Triton X-100, 1 mM orthovanadate, $270 \mathrm{mM}$ sucrose, $1 \mathrm{mM}$ sodium glycerophosphate, $5 \mathrm{mM}$ sodium fluoride, $1 \mathrm{mM}$ sodium pyrophosphate, $5 \mathrm{mM} \beta$-mercaptoethanol, $1 \mathrm{mM}$ benzamidine, $35 \mu \mathrm{g} / \mathrm{mL}$ PMSF, and $5 \mu \mathrm{g} / \mathrm{mL}$ leupeptin). Samples were homogenized, ultra-sonicated, and incubated on ice for $20 \mathrm{~min}$, before centrifuging at $12,000 \times g$, for $15 \mathrm{~min}$. Supernatants were used to calculate the protein concentration, which was evaluated by the Bradford method. For Western blot analysis, a sample of 25 to $50 \mu \mathrm{g}$ of total protein was used. The proteins were separated on $15 \%$ sodium dodecyl sulfate (SDS)-polyacrylamide gel and transferred to polyvinylidene difluoride membranes. The membranes were blocked by incubation for $1 \mathrm{~h}$ in TBS buffer containing $0.1 \%$ Tween and $5 \%$ milk powder at room temperature and washed with TBS buffer containing $0.1 \%$ Tween. The membranes were blotted overnight at $4{ }^{\circ} \mathrm{C}$, with primary antibodies: rabbit polyclonal interleukin IL-1 $\beta$ (1/200 dilution), goat polyclonal TNF $\alpha$ (1/100 dilution), goat polyclonal $\mathrm{p}-\mathrm{I} \kappa \mathrm{B} \alpha(1 / 200$ dilution), rabbit polyclonal NOS2 (1/200 dilution), and goat polyclonal COX-2 (1/500 dilution). The blots were then washed 3 times with TBS- $0.1 \%$ Tween, and developed with secondary antibodies bound to peroxidase, for $1 \mathrm{~h}$ at room temperature (1/3000 dilution). The blots were then washed 3 times with TBS-0.1\% Tween and once with TBS. Afterwards, all blots were revealed using the ChemiDoc XRS Image System (Bio-Rad Laboratories, Hercules, CA, USA). The protein bands were quantified using the Multi-Gauge program (Fuji Film Europe, TK Tiburg, Holland). The data of protein expression were expressed as means \pm S.D. of at least three experiments performed in duplicate for each concentration.

\subsection{Animals}

Male BL/6J mice, 8 weeks old and weighing 21-28 g, were purchased from the Animal Experimentation Service of the Center for Scientific Instrumentation of the University of Granada (Spain). These mice were housed for 7 days at $22{ }^{\circ} \mathrm{C}$ with $70 \%$ humidity, a $12 \mathrm{~h}$ light/dark cycle and were fed a standard diet and water was provided ad libitum before experimentation. The experiment was conducted following the guidelines issued by the Animal Care Committee and accepted by the Institutional Ethics Committee of the University of Granada.

\subsection{TPA-Induced Acute Ear Edema}

Edema was induced by topical administration of TPA in acetone, specifically $2.5 \mu \mathrm{g} / \mathrm{ear}$. In groups of 8 individuals, the mice were treated on both surfaces of the right ear using a $20-\mu \mathrm{L}$ solution of acetone containing OADP $(0.5 \mathrm{mg} / \mathrm{ear})$, while the reference group was treated similarly using diclofenac $(0.5 \mathrm{mg} /$ ear $)$ as a reference drug, the control group was not treated with any anti-inflammatory compound. Simultaneously, the TPA was placed 
on both sides of the right ear at 0,6 , and $18 \mathrm{~h}$. At $6 \mathrm{~h}$ after the end of the last treatment, the animals underwent cervical dislocation. The samples were then stored at $-80{ }^{\circ} \mathrm{C}$. The left ear was treated with acetone only, as a control. A 6-mm diameter disc was removed from treated as well as untreated ears and weighed separately on an analytical balance. The degree of edema was determined by the weight increase of the right ear over the left. The anti-inflammatory effect was evaluated as a percentage of the suppression of edema in the treated groups in contrast to the control group. A series of morphological measurements were taken in these tissues, such as length, width, thickness, diameter of the external auditory canal, and weight, as detailed below. Length measurements were made with a precision digital caliper.

\subsection{Histology Study of Acute Ear Edema}

The ears of the mice were treated as described above. Subsequently, they were cut and fixed in $4 \%$ PFA for $24 \mathrm{~h}$. After three washes in PBS, they were embedded in paraffin and cut into sections on a microtome (Zeiss). The sections were stained with hematoxylin and eosin. Images were taken using an Axiophot microscope (Zeiss) with a magnification of $125 \times$. For its quantification, the thickness of the ear was measured using ImageJ imaging software (NIH) and expressed as mean \pm standard error of the mean (S.E.M.). Student's t-test was applied for the statistical analysis, and a value of $p<0.05$ was considered statistically significant.

\subsection{Interleukin-6 Release}

After the activation of the inflammation process, key proteins that mediate this process are induced. These proteins are cytokines and proteins responsible for the arachidonic acid cascade. The concentration levels of IL-6 were analyzed as markers of inflammation in the aforementioned different groups of mice.

The tissue samples were washed with cold PBS and then homogenized at 10\% tissue concentration in homogenization buffer (PBS, 0.1 M PMSF, 0.5\% BSA, $10 \mathrm{mM}$ EDTA, leupeptin $5 \mu \mathrm{g} / \mathrm{mL}$ ). Two freeze-thaw cycles were performed to break down the cell membranes. The homogenates were centrifuged at $5000 \times g$ for $5 \mathrm{~min}$. Finally, the supernatants were removed and immediately analyzed for the cytokine concentration. The IL- 6 concentration was determined by the ELISA technique, using a specific kit (E0079m, EIAab Science Co., Wuhan, China). The percentage of IL-6 inhibition was calculated according to:

$$
\% I L_{6} \text { inhibition }=\left\{1-\frac{\left(\left[I L_{6}\right]_{\text {ear } r_{\text {right }}}-\left[I L_{6}\right]_{\text {ear }} \text { left }_{\text {sample }}\right.}{\left.\left.\left(\left[I L_{6}\right]_{\text {ear }}\right)_{\text {right }}-\left[I L_{6}\right]_{\text {ear }}\right)_{\text {left }}\right)_{\text {control }}}\right\} \times 100
$$

\subsection{Statistical Analysis}

The data are represented as the mean \pm standard deviation (S.D.). For each assay, the Student's t-test was used for statistical comparisons with control cells. A limit of $p \leq 0.05$ was used to assess significant differences: $p<0.05\left(^{*}\right), p<0.01\left({ }^{* *}\right)$ and $p<0.001\left(^{* * *}\right)$. The data shown are representative of at least two independent experiments performed in triplicate.

\section{Conclusions}

In the present study, we demonstrate that OADP has a powerful anti-inflammatory effect in vitro and in vivo in the models evaluated. Moreover, we deduced the underlying molecular mechanism for the anti-inflammatory effect of OADP on LPS-stimulated RAW 264.7 cells, after $72 \mathrm{~h}$ of treatment, at concentrations of $\frac{1}{2} \mathrm{IC}_{50}$ and $\frac{3}{4} \mathrm{IC}_{50}$. That is, OADP weakened the expression of pro-inflammatory cytokines such as TNF $\alpha$ and IL- $\beta$ in LPSstimulated macrophages. This in turn decreased inflammatory proteins such as iNOS and COX-2 and inhibited NO production, a crucial inflammatory mediator. Furthermore, IкB $\alpha$ phosphorylation was significantly suppressed after $72 \mathrm{~h}$ of OADP treatment. 
Among the most outstanding results of this study is the potent anti-inflammatory effect of OADP in LPS-stimulated RAW 264.7 cells and in mice with acute ear edema. The results demonstrate that OADP inhibits NO production and reverses the differentiation processes in LPS-stimulated RAW 264.7 cells. Furthermore, OADP impedes the expression of TNF- $\alpha$, IL- $1 \beta$, iNOS, and COX-2, as well as blocking the production of $\mathrm{p}-\mathrm{I} \mathrm{KB} \alpha$ in these macrophage cells. Based on these results, the following mechanism is suggested for the anti-inflammatory effect of OADP in these macrophage cells. Firstly, OADP diminishes the expression of TNF- $\alpha$ and IL-1 $\beta$ and decreases iNOS as well as COX-2, which in turn subsequently hinders $\mathrm{p}-\mathrm{I} \mathrm{K} \mathrm{B} \alpha$ and NO production (Figure 11). Thus, these results suggest the possible pharmacological use of OADP as a potent and effective anti-inflammatory agent in acute and chronic inflammatory diseases.

Author Contributions: Conceptualization, M.M.-O., F.R. and F.J.R.-Z.; Formal analysis, F.J., M.M.-O., V.E.N., M.J.S.-L., M.R.S., J.A.L., A.P. and F.J.R.-Z.; Funding acquisition, F.R., J.A.L., A.P. and F.J.R.-Z.; Investigation, F.J., M.M.-O., V.E.N., M.M., M.J.S.-L., M.R.S., E.E.R.-P., A.M. and F.J.R.-Z.; Methodology, M.M.-O., A.M., F.R., M.J.S.-L., M.R.S., E.E.R.-P. and F.J.R.-Z.; Project administration, F.R. and F.J.R.Z.; Resources, M.M.-O., F.R., E.E.R.-P., J.A.L., A.P. and F.J.R.-Z.; Supervision, J.A.L., A.P., F.R. and F.J.R.-Z.; Validation, F.J., M.M.-O., V.E.N., M.R.S.,E.E.R.-P., J.A.L., A.P. and F.J.R.-Z.; Visualization, F.J., M.M.-O., V.E.N., M.R.S., F.R. and F.J.R.-Z.; Writing-original draft, F.J., M.M.-O., F.R. and F.J.R.-Z.; Writing-review \& editing, F.R. and F.J.R.-Z. All authors have read and agreed to the published version of the manuscript.

Funding: This research was funded by the "Consejería de Economía, Conocimiento, Empresas y Universidad. Junta de Andalucía", grant numbers B1-BIO-281-UGR18 and B1-FQM-217-UGR18.

Institutional Review Board Statement: The study was conducted and approved in accordance with the guidelines of the Ethics Committee for Animal Experimentation of the University of Granada (283-CEEA-OH-2019).

Informed Consent Statement: Not applicable.

Data Availability Statement: Not applicable.

Acknowledgments: We thank the CIC service of the University of Granada for their support and David Nesbitt for reviewing the English of the manuscript.

Conflicts of Interest: The authors declare no conflict of interest. The funders had no role in the design of the study; in the collection, analyses, or interpretation of data; in the writing of the manuscript, or in the decision to publish the results.

$\begin{array}{ll}\text { Abbreviations } \\ \text { AP-1 } & \text { Activatior protein 1 } \\ \text { COX-2 } & \text { Cyclooxygenase-2 } \\ \text { IC }_{50} & \text { Total concentration to obtain a 50\% cell growth inhibition } \\ \text { IC }_{50 \text { NO }} & \text { Doses that result in } 50 \% \text { NO inhibition } \\ \text { IL } & \text { Interleukin } \\ \text { INF- } \gamma & \text { Interferon- } \gamma \\ \text { iNOS } & \text { Inducible nitric oxide synthase } \\ \text { PI } & \text { Propidium iodide } \\ \text { IKB } \alpha & \text { NF- } k \text { B inhibitory protein alpha } \\ \text { JAK } & \text { Janus-activated kinase } \\ \text { LPS } & \text { Bacterial lipopolysaccharide } \\ \text { MAPK } & \text { Mitogen-activated protein kinase } \\ \text { NF- } \text { B } & \text { Nuclear factor kappa B } \\ \text { NO } & \text { Nitric oxide } \\ \text { NSAID } & \text { Nonsteroidal anti-inflammatory drug } \\ \text { OADP } & \text { Diamine-PEGylated derivative of oleanolic acid } \\ \text { PI3K/AKT } & \text { Phosphatidylinositol-3-kinase }\end{array}$




$\begin{array}{ll}\text { STAT } & \text { Signal transducer activator of transcription } \\ \text { TLR } & \text { Toll-like receptor } \\ \text { TNF } \alpha & \text { Tumor necrosis factor } \alpha \\ \text { TPA } & \text { 12-O-tetra-decanocanoylphorbol-13-acetate }\end{array}$

\section{References}

1. Hankittichai, P.; Buacheen, P.; Pitchakarn, P.; Na Takuathung, M.; Wikan, N.; Smith, D.R.; Potikanond, S.; Nimlamool, W. Artocarpus lakoocha Extract Inhibits LPS-Induced Inflammatory Response in RAW 264.7 Macrophage Cells. Int. J. Mol. Sci. 2020, 21, 1355. [CrossRef]

2. Galisteo, A.; Jannus, F.; García-García, A.; Aheget, H.; Rojas, S.; Lupiañez, J.; Rodríguez-Diéguez, A.; Reyes-Zurita, F.; del Moral, J.Q. Diclofenac N-Derivatives as Therapeutic Agents with Anti-Inflammatory and Anti-Cancer Effect. Int. J. Mol. Sci. 2021, 22, 5067. [CrossRef] [PubMed]

3. Xiong, H.; Zheng, Y.; Yang, G.; Wang, H.; Mei, Z. Triterpene saponins with anti-inflammatory activity from the stems of Entada phaseoloides. Fitoterapia 2015, 103, 33-45. [CrossRef] [PubMed]

4. Li, J.; Jing, J.; Bai, Y.; Li, Z.; Xing, R.; Tan, B.; Ma, X.; Qiu, W.-W.; Du, C.; Du, B.; et al. SH479, a Betulinic Acid Derivative, Ameliorates Experimental Autoimmune Encephalomyelitis by Regulating the T Helper 17/Regulatory T Cell Balance. Mol. Pharmacol. 2017, 91, 464-474. [CrossRef]

5. Martín, R.; Cordova, C.; Román, J.S.; Gutierrez, B.; Cachofeiro, V.; Nieto, M. Oleanolic acid modulates the immune-inflammatory response in mice with experimental autoimmune myocarditis and protects from cardiac injury. Therapeutic implications for the human disease. J. Mol. Cell. Cardiol. 2014, 72, 250-262. [CrossRef] [PubMed]

6. Kim, M.; Lee, S.; Lim, H.; Lee, J.; Park, J.-Y.; Kwon, H.-J.; Lee, I.-C.; Ryu, Y.-B.; Kim, J.; Shin, T.; et al. Oleanolic Acid Acetate Alleviates Symptoms of Experimental Autoimmune Encephalomyelitis in Mice by Regulating Toll-Like Receptor 2 Signaling. Front. Pharmacol. 2020, 11, 556391. [CrossRef] [PubMed]

7. Fitzpatrick, L.R.; Stonesifer, E.; Small, J.S.; Liby, K.T. The synthetic triterpenoid (CDDO-Im) inhibits STAT3, as well as IL-17, and improves DSS-induced colitis in mice. Inflammopharmacology 2014, 22, 341-349. [CrossRef] [PubMed]

8. Rali, S.; Oyedeji, O.O.; Aremu, O.O.; Oyedeji, A.; Nkeh-Chungag, B.N. Semisynthesis of Derivatives of Oleanolic Acid fromSyzygium aromaticumand Their Antinociceptive and Anti-Inflammatory Properties. Mediat. Inflamm. 2016, 2016, 1-9. [CrossRef]

9. Nkeh-Chungag, B.N.; Oyedeji, O.O.; Oyedeji, A.; Ndebia, E.J. Anti-Inflammatory and Membrane-Stabilizing Properties of Two Semisynthetic Derivatives of Oleanolic Acid. Inflammation 2015, 38, 61-69. [CrossRef] [PubMed]

10. Stiti, N.; Triki, S.; Hartmann, M.-A. Formation of Triterpenoids throughout Olea europaea Fruit Ontogeny. Lipids 2007, $42,55-67$. [CrossRef]

11. Pérez-Camino, M.C.; Cert, A. Quantitative determination of hydroxy pentacyclic triterpene acids in vegetable oils. J. Agric. Food Chem. 1999, 47, 1558-1562. [CrossRef]

12. Martínez, A.; Perojil, A.; Rivas, F.; Parra, A.; Garcia-Granados, A.; Fernandez-Vivas, A. Biotransformation of oleanolic and maslinic methyl esters by Rhizomucor miehei CECT 2749. Phytochemistry 2015, 117, 500-508. [CrossRef]

13. Zukancic, D.; Suys, E.J.A.; Pilkington, E.H.; Algarni, A.; Al-Wassiti, H.; Truong, N.P. The Importance of Poly(ethylene glycol) and Lipid Structure in Targeted Gene Delivery to Lymph Nodes by Lipid Nanoparticles. Pharmaceutics 2020, 12, 1068. [CrossRef] [PubMed]

14. Medina-O'Donnell, M.; Rivas, F.; Reyes-Zurita, F.J.; Martinez, A.; Lupiañez, J.A.; Parra, A. Diamine and PEGylated-diamine conjugates of triterpenic acids as potential anticancer agents. Eur. J. Med. Chem. 2018, 148, 325-336. [CrossRef] [PubMed]

15. Medina-O'Donnell, M.; Rivas, F.; Reyes-Zurita, F.J.; Martinez, A.; Galisteo-González, F.; Lupiañez, J.A.; Parra, A. Synthesis and in vitro antiproliferative evaluation of PEGylated triterpene acids. Fitoterapia 2017, 120, 25-40. [CrossRef] [PubMed]

16. O’Donnell, M.M.; Rivas, F.; Reyes-Zurita, F.J.; Martinez, A.; Martin-Fonseca, S.; Garcia-Granados, A.; Ferrer-Martín, R.M.; Lupiañez, J.A.; Parra, A. Semi-synthesis and antiproliferative evaluation of PEGylated pentacyclic triterpenes. Eur. J. Med. Chem. 2016, 118, 64-78. [CrossRef]

17. Jannus, F.; Medina-O’Donnell, M.; Rivas, F.; Díaz-Ruiz, L.; Rufino-Palomares, E.E.; Lupiáñez, J.A.; Parra, A.; Reyes-Zurita, F.J A Diamine-PEGylated Oleanolic Acid Derivative Induced Efficient Apoptosis through a Death Receptor and Mitochondrial Apoptotic Pathway in HepG2 Human Hepatoma Cells. Biomolecules 2020, 10, 1375. [CrossRef] [PubMed]

18. Bondar, T.; Medzhitov, R. The Origins of Tumor-Promoting Inflammation. Cancer Cell 2013, 24, 143-144. [CrossRef] [PubMed]

19. Steelman, L.S.; Pohnert, S.C.; Shelton, J.G.; Franklin, R.A.; Bertrand, F.E.; McCubrey, J.A. JAK/STAT, Raf/MEK/ERK, PI3K/Akt and BCR-ABL in cell cycle progression and leukemogenesis. Leukemia 2004, 18, 189-218. [CrossRef]

20. Lee, S.; Shin, S.; Kim, H.; Han, S.; Kim, K.; Kwon, J.; Kwak, J.-H.; Lee, C.-K.; Ha, N.-J.; Yim, D.; et al. Anti-inflammatory function of arctiin by inhibiting COX-2 expression via NF-кB pathways. J. Inflamm. 2011, 8, 16. [CrossRef]

21. Wang, A.; Al-Kuhlani, M.; Johnston, S.C.; Ojcius, D.; Chou, J.; Dean, D. Transcription factor complex AP-1 mediates inflammation initiated byChlamydia pneumoniaeinfection. Cell. Microbiol. 2013, 15, 779-794. [CrossRef] [PubMed]

22. Kawahara, K.; Hohjoh, H.; Inazumi, T.; Tsuchiya, S.; Sugimoto, Y. Prostaglandin E2-induced inflammation: Relevance of prostaglandin E receptors. Biochim. Biophys. Acta (BBA) Mol. Cell Biol. Lipids 2015, 1851, 414-421. [CrossRef] [PubMed]

23. Salvemini, D.; Kim, S.F.; Mollace, V. Reciprocal regulation of the nitric oxide and cyclooxygenase pathway in pathophysiology: Relevance and clinical implications. Am. J. Physiol. Integr. Comp. Physiol. 2013, 304, R473-R487. [CrossRef] [PubMed] 
24. Gábor, M. Models of Acute Inflammation in the Ear. Inflamm. Protoc. 2003, 225, 129-138. [CrossRef]

25. Lee, S.H.; Kim, D.W.; Eom, S.A.; Jun, S.-Y.; Park, M.-Y.; Kim, D.-S.; Kwon, H.J.; Kwon, H.Y.; Han, K.H.; Park, J.-S.; et al. Suppression of 12-O-tetradecanoylphorbol-13-acetate (TPA)-induced skin inflammation in mice by transduced Tat-Annexin protein. BMB Rep. 2012, 45, 354-359. [CrossRef] [PubMed]

26. Furman, D.; Campisi, J.; Verdin, E.; Carrera-Bastos, P.; Targ, S.; Franceschi, C.; Ferrucci, L.; Gilroy, D.W.; Fasano, A.; Miller, G.W.; et al. Chronic inflammation in the etiology of disease across the life span. Nat. Med. 2019, 25, 1822-1832. [CrossRef] [PubMed]

27. Zappavigna, S.; Cossu, A.M.; Grimaldi, A.; Bocchetti, M.; Ferraro, G.A.; Nicoletti, G.F.; Filosa, R.; Caraglia, M. Anti-Inflammatory Drugs as Anticancer Agents. Int. J. Mol. Sci. 2020, 21, 2605. [CrossRef]

28. Ayeleso, T.B.; Matumba, M.G.; Mukwevho, E. Oleanolic Acid and Its Derivatives: Biological Activities and Therapeutic Potential in Chronic Diseases. Molecules 2017, 22, 1915. [CrossRef] [PubMed]

29. Laskin, D.L. Macrophages and Inflammatory Mediators in Chemical Toxicity: A Battle of Forces. Chem. Res. Toxicol. 2009, 22, 1376-1385. [CrossRef] [PubMed]

30. Kang, S.-R.; Han, D.-Y.; Park, K.-I.; Park, H.-S.; Cho, Y.-B.; Lee, H.-J.; Lee, W.-S.; Ryu, C.H.; Ha, Y.L.; Lee, D.H.; et al. Suppressive Effect on Lipopolysaccharide-Induced Proinflammatory Mediators byCitrus aurantium L.in Macrophage RAW 264.7 Cells via NF-кB Signal Pathway. Evid.-Based Complement. Altern. Med. 2011, 2011, 1-12. [CrossRef]

31. McWhorter, F.; Wang, T.; Nguyen, P.; Chung, T.; Liu, W.F. Modulation of macrophage phenotype by cell shape. Proc. Natl. Acad. Sci. USA 2013, 110, 17253-17258. [CrossRef]

32. Tseng, H.-Y.; Wu, S.-H.; Huang, W.-H.; Wang, S.-F.; Yang, Y.-N.; Mahindroo, N.; Hsu, T.; Jiaang, W.-T.; Lee, S.-J. Benzothiazolium compounds: Novel classes of inhibitors that suppress the nitric oxide production in RAW264.7 cells stimulated by LPS/IFN $\gamma$. Bioorg. Med. Chem. Lett. 2005, 15, 2027-2032. [CrossRef] [PubMed]

33. Fang, L.; Wang, K.-K.; Huang, Q.; Cheng, F.; Huang, F.; Liu, W.-W. Nucleolin Mediates LPS-induced Expression of Inflammatory Mediators and Activation of Signaling Pathways. Curr. Med. Sci. 2020, 40, 646-653. [CrossRef]

34. Mori, T.; Miyamoto, T.; Yoshida, H.; Asakawa, M.; Kawasumi, M.; Kobayashi, T.; Morioka, H.; Chiba, K.; Toyama, Y.; Yoshimura, A. IL-1 and TNF-initiated IL-6-STAT3 pathway is critical in mediating inflammatory cytokines and RANKL expression in inflammatory arthritis. Int. Immunol. 2011, 23, 701-712. [CrossRef]

35. Checker, R.; Sandur, S.K.; Sharma, D.; Patwardhan, R.S.; Jayakumar, S.; Kohli, V.; Sethi, G.; Aggarwal, B.B.; Sainis, K.B. Potent Anti-Inflammatory Activity of Ursolic Acid, a Triterpenoid Antioxidant, Is Mediated through Suppression of NF- $\mathrm{k}$, AP-1 and NF-AT. PLoS ONE 2012, 7, e31318. [CrossRef]

36. Dong, N.; Xue, C.; Zhang, L.; Zhang, T.; Wang, C.; Bi, C.; Shan, A. Oleanolic acid enhances tight junctions and ameliorates inflammation in Salmonella typhimurium-induced diarrhea in mice via the TLR4/NF-kB and MAPK pathway. Food Funct. 2020, 11, 1122-1132. [CrossRef] [PubMed]

37. Jin, J.; He, H.; Zhang, X.; Wu, R.; Gan, L.; Li, D.; Lu, Y.; Wu, P.; Wong, W.-L.; Zhang, K. The in vitro and in vivo study of oleanolic acid indole derivatives as novel anti-inflammatory agents: Synthesis, biological evaluation, and mechanistic analysis. Bioorganic Chem. 2021, 113, 104981. [CrossRef]

38. Fernández, M.A.; Heras, B.D.L.; Garcia-Gimenez, M.D.; Sáenz, M.T.; Villar, A. New insights into the mechanism of action of the anti-inflammatory triterpene lupeol. J. Pharm. Pharmacol. 2001, 53, 1533-1539. [CrossRef]

39. Huang, L.; Guan, T.; Qian, Y.; Huang, M.; Tang, X.; Li, Y.; Sun, H. Anti-inflammatory effects of maslinic acid, a natural triterpene, in cultured cortical astrocytes via suppression of nuclear factor-kappa B. Eur. J. Pharmacol. 2011, 672, 169-174. [CrossRef] [PubMed]

40. Reyes-Zurita, F.J.; Pachón-Peña, G.; Lizárraga, D.; Rufino-Palomares, E.E.; Cascante, M.; Lupiáñez, J.A. The natural triterpene maslinic acid induces apoptosis in HT29 colon cancer cells by a JNK-p53-dependent mechanism. BMC Cancer 2011, 11, 154. [CrossRef] [PubMed]

41. Sánchez-Tena, S.; Reyes-Zurita, F.J.; Diaz-Moralli, S.; Vinardell, M.P.; Reed, M.; Garcia-Garcia, F.; Dopazo, J.; Lupiáñez, J.A.; Günther, U.; Cascante, M. Maslinic Acid-Enriched Diet Decreases Intestinal Tumorigenesis in ApcMin/+ Mice through Transcriptomic and Metabolomic Reprogramming. PLoS ONE 2013, 8, e59392. [CrossRef] [PubMed]

42. Kang, G.-D.; Lim, S.; Kim, D.-H. Oleanolic acid ameliorates dextran sodium sulfate-induced colitis in mice by restoring the balance of Th17/Treg cells and inhibiting NF-kB signaling pathway. Int. Immunopharmacol. 2015, 29, 393-400. [CrossRef] [PubMed]

43. Dinh, C.H.L.; Yu, Y.; Szabo, A.; Zhang, Q.; Zhang, P.; Huang, X.-F. Bardoxolone Methyl Prevents High-Fat Diet-Induced Colon Inflammation in Mice. J. Histochem. Cytochem. 2016, 64, 237-255. [CrossRef]

44. Ahmad, S.F.; Ansari, M.A.; Zoheir, K.; Bakheet, S.A.; Korashy, H.M.; Nadeem, A.; Ashour, A.E.; Attia, S.M. Regulation of TNF- $\alpha$ and NF- $\mathrm{KB}$ activation through the JAK/STAT signaling pathway downstream of histamine 4 receptor in a rat model of LPS-induced joint inflammation. Immunobiol. 2015, 220, 889-898. [CrossRef] [PubMed]

45. Kim, S.F.; Huri, D.A.; Snyder, S.H. Inducible Nitric Oxide Synthase Binds, S-Nitrosylates, and Activates Cyclooxygenase-2. Science 2005, 310, 1966-1970. [CrossRef] [PubMed]

46. Kao, E.-S.; Wang, C.-J.; Lin, W.-L.; Yin, Y.-F.; Wang, C.-P.; Tseng, T.-H. Anti-inflammatory Potential of Flavonoid Contents from Dried Fruit of Crataegus pinnatifida in Vitro and in Vivo. J. Agric. Food Chem. 2005, 53, 430-436. [CrossRef]

47. Li, H.-J.; Wu, N.-L.; Lee, G.-A.; Hung, C.-F. The Therapeutic Potential and Molecular Mechanism of Isoflavone Extract against Psoriasis. Sci. Rep. 2018, 8, 6335. [CrossRef] 
48. Medeiros, R.; Otuki, M.; Avellar, M.C.W.; Calixto, J.B. Mechanisms underlying the inhibitory actions of the pentacyclic triterpene $\alpha$-amyrin in the mouse skin inflammation induced by phorbol ester 12-O-tetradecanoylphorbol-13-acetate. Eur. J. Pharmacol. 2007, 559, 227-235. [CrossRef]

49. Vasconcelos, J.; Teixeira, M.; Filho, J.M.B.; Lúcio, A.; Almeida, J.; de Queiroz, L.P.; Ribeiro-Dos-Santos, R.; Soares, M. The triterpenoid lupeol attenuates allergic airway inflammation in a murine model. Int. Immunopharmacol. 2008, 8, 1216-1221. [CrossRef]

50. Geetha, T.; Varalakshmi, P. Anticomplement activity of triterpenes from Crataeva nurvala stem bark in adjuvant arthritis in rats. Gen. Pharmacol. Vasc. Syst. 1999, 32, 495-497. [CrossRef]

51. Abel, E.; Angel, J.M.; Kiguchi, K.; DiGiovanni, J. Multi-stage chemical carcinogenesis in mouse skin: Fundamentals and applications. Nat. Protoc. 2009, 4, 1350-1362. [CrossRef] [PubMed]

52. Chiocchio, I.; Prata, C.; Mandrone, M.; Ricciardiello, F.; Marrazzo, P.; Tomasi, P.; Angeloni, C.; Fiorentini, D.; Malaguti, M.; Poli, F.; et al. Leaves and Spiny Burs of Castanea Sativa from an Experimental Chestnut Grove: Metabolomic Analysis and Anti-Neuroinflammatory Activity. Metabolites 2020, 10, 408. [CrossRef] [PubMed] 